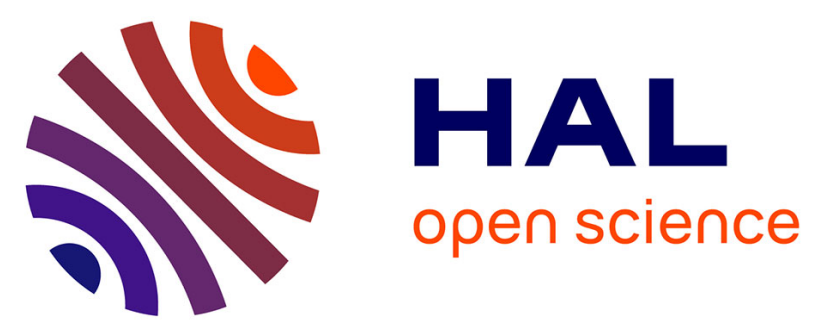

\title{
Interdisciplinary characterisation and environmental imprints of mining and forestry in the upper Durance valley (France) during the Holocene
}

Vanessa Py, Alain Veron, Jean-Louis Édouard, Jacques-Louis de Beaulieu, Bruno Ancel, Maxence Segard, Aline Durand, Philippe Leveau

\section{To cite this version:}

Vanessa Py, Alain Veron, Jean-Louis Édouard, Jacques-Louis de Beaulieu, Bruno Ancel, et al.. Interdisciplinary characterisation and environmental imprints of mining and forestry in the upper Durance valley (France) during the Holocene. Quaternary International, 2014, 353, pp.74-97. 10.1016/j.quaint.2014.05.002 . hal-01131960

\section{HAL Id: hal-01131960 \\ https://hal-univ-tlse2.archives-ouvertes.fr/hal-01131960}

Submitted on 16 Mar 2015

HAL is a multi-disciplinary open access archive for the deposit and dissemination of scientific research documents, whether they are published or not. The documents may come from teaching and research institutions in France or abroad, or from public or private research centers.
L'archive ouverte pluridisciplinaire HAL, est destinée au dépôt et à la diffusion de documents scientifiques de niveau recherche, publiés ou non, émanant des établissements d'enseignement et de recherche français ou étrangers, des laboratoires publics ou privés. 


\title{
Interdisciplinary characterisation and environmental imprints of mining and forestry in the upper Durance valley (France) during the Holocene
}

\author{
Vanessa Py $^{\mathrm{a}, *}$, Alain Véron ${ }^{\mathrm{b}}$, Jean-Louis Edouard ${ }^{\mathrm{c}}$, Jacques-Louis de Beaulieu ${ }^{\mathrm{d}}$, Bruno Ancel ${ }^{\mathrm{e}, \mathrm{f}}$, \\ Maxence Segard $^{\mathrm{C}}$, Aline Durand ${ }^{\mathrm{g}}$, Philippe Leveau ${ }^{\mathrm{C}}$ \\ ${ }^{a}$ GEODE, UMR 5602, CNRS, Université Toulouse-Jean Jaurés, Maison de la Recherche, 5 Allée Antonio Machado, 31058 Toulouse Cedex 1, France \\ ${ }^{\mathrm{b}}$ CEREGE, UM 34, CNRS, Université Aix-Marseille, IRD, Europôle Méditerranéen de l'Arbois, Av. Louis Philibert, BP 80, 13545 Aix-en-Provence cedex 04, \\ France \\ ${ }^{c}$ CCJ, UMR 7299, CNRS, Université Aix-Marseille, Maison Méditerranéenne des Sciences de l'Homme, 5 rue du Château de l'Horloge, \\ BP 64713094 Aix-en-Provence cedex, France \\ ${ }^{\mathrm{d}}$ IMBE, UMR 7263, CNRS, Université Aix-Marseille, Europôle Méditerranéen de l'Arbois, Bat. Villemin, BP 80, 13545 Aix-en-Provence cedex 04, France \\ e TRACES, UMR 5608, CNRS, Université Toulouse-Jean Jaurés, Maison de la Recherche, 5 Allée Antonio Machado, 31058 Toulouse Cedex 9, France \\ ${ }^{\mathrm{f}}$ Service Culturel Municipal de L'Argentière-La Bessée, Mairie de L'Argentière, 05120 L'Argentière-La Bessée, France \\ ${ }^{g}$ CReAAH, UMR 6566, CNRS-LUNAM, Université du Maine, Avenue Olivier Messiaen, 72085 Le Mans cedex 9, France
}

\section{A R T I C L E I N F O}

\section{Article history:}

Available online 29 May 2014

\section{Keywords:}

Mining

Forestry

French Southern Alps

Lead isotopes

Pollen and charcoal

Holocene

\begin{abstract}
A B S T R A C T
The upper Durance valley contains the largest silver-lead mines of the French Southern Alps. We investigated the characterisation and impact of these mining activities and associated forestry in the Argentière (L'Argentière-La Bessée) and Faravel (Freissinières) districts using a multidisciplinary approach that includes archaeological, palynological, geochemical, anthracological and dendrochronological studies applied to mining remnants and a peat bog (Fangeas, in the Faravel district). More specifically, we studied the occurrence of lead contamination episodes, the chronology of mining activities and their link to the evolution in woodland cover. Our chronology is based on mining archaeology, radiocarbon dating of about thirty charcoal samples and the dendrochronological analysis of more than 170 specimens of exhumed waterlogged wood. The anthracological analysis was established with more than 10,000 charcoals from firesetting. The main geochemical approach was based on the analysis of lead and its stable isotopes in sediment fractions from a peat core. The combination of palynological records and lead isotope imprints were used to characterise (i) a Roman contamination episode unknown to archaeology, (ii) the development of medieval mining activities and (iii) the reactivation of mining during the Modern period and the Industrial Revolution. Medieval mining coincides with an extension of the high mountain agropastoral areas. The in situ continuous human activities in the same industrial territory led to rational communal management of subalpine forests, but also to their parcelling that reached its peak in the High Middle Ages. Mining during the Modern period coincides with significant stress on woodland areas that also appears to be related to lumber and fuel timber production for shipyards (French Royal Navy) as well as the functioning of several military fortresses. The mining reactivation during the 19th $\mathrm{c}$. matched public measures of forest protection that took shape in the afforestation programme of the uplands.
\end{abstract}

() 2014 Elsevier Ltd and INQUA. All rights reserved.

\footnotetext{
* Corresponding author.

E-mail address: vanessa.py@univ-tlse2.fr (V. Py).
}

\section{Introduction}

Mining, ore processing and their links to forestry and woodland evolution have been widely investigated since the 1970-80s with the combined study of written sources and archaeological charcoal (i.e. Bielenin, 1974; Bonhôte and Vernet, 1988; Métailié et al., 1988; Hillebrecht, 1989). Earlier researches were conducted in the 
Pyrenees and in the Black Forest in the 1990s (i.e. Ludemann, 1995; Davasse, 2000; Montanari et al., 2000; Bonhôte et al., 2002; Ludemann and Nelle, 2002) before spreading to other European regions (Gale, 2003; Bond, 2007; Allée et al., 2010). They comprised multidisciplinary approaches that included (i) pollen and charcoal kiln analyses (Davasse and Galop, 1989; Galop and Jalut, 1994), or (ii) dendrochronological analysis of mine timbers (Pichler et al., 2009), or (iii) anthracological study of firesetting charcoals (Téreygeol and Dubois, 2003; Heiss and Oeggl, 2008; Barge and Talon, 2012; Py et al., 2013) or (iv) the analysis of micro- and macro-remains from mining sediments (Mighall et al., 2002a). More recently, the combination of palynological and geochemical analyses has been used to further define human/environment interactions with a renewed approach of mining chronology and the characterisation of environmental imprints from mining, associated activities and metal filiation (Mighall et al., 2002b; Shotyk, 2002; Monna et al., 2004; Baron et al., 2005; Jouffroy-Bapicot et al., 2007; Breitenlechner et al., 2010; Cattin et al., 2011; Garçon et al., 2012). In some cases, such methodology gave rise to a clear connection of mining activities including ore-extraction, its metallurgy and post-glacial processes of anthropisation (Galop et al., 2006; Gassiot et al., 2010). When evident, human occupation and their endeavours are closely linked to the exploitation of natural resources, in particular ores, forests and grasslands. However, a complete multidisciplinary approach that would include archaeological, historical, dendrochronological, dendrological and anthracological data along with geochemical analyses is rarely considered. The upper Durance valley (French Southern Alps) offers a unique opportunity to conduct such an approach thanks to numerous archaeological remains and natural proxies that have recorded human and natural imprints during the Holocene. These resources have led to the development of several multidisciplinary programmes based on human/environment interactions (Beaulieu et al., 2003; Walsh et al., 2014) and mining history (Py and Ancel, 2007; Ancel et al., 2010; Py, 2010). Here, we present a multidisciplinary synthesis of mining activities in the upper Durance valley and its influence on environmental changes since the Protohistory. In particular, we focus on two mining sequences that are scantily or not at all documented by both written sources: the Roman era and the Middle Ages. We propose to further constrain mining chronology and to recognize potential new periods of activities using archaeological, palynological, geochemical, anthracological, dendrological, dendrochronological and historical data analyses within the same micro study window. More particularly, we aim to comprehend woodland management associated with mining as well as artisanal and industrial practices and to what extent mining is responsible for the degradation of mountain and subalpine environments.

\section{Regional setting}

\subsection{Archaeological and historical background}

Archaeological investigations conducted in the upper Durance valley have revealed continuous human presence in the subalpine area since the Mesolithic (Walsh et al., 2010, 2014). Mining activities are well identified during the Medieval, Modern and Contemporary periods. Silver-lead mines at L'Argentière-La Bessée (Fig. 1) constitute one of the largest mining districts of the French Southern Alps (Ancel, 2010; Ancel et al., 2010) that has been investigated owing to several archaeological excavations and heritage enhancements. Medieval mining works were developed with opencast (over $2400 \mathrm{~m}^{2}$ ) and underground for nearly $2 \mathrm{~km}$. The total volume of excavated mineralisation was estimated at $22,000 \mathrm{~m}^{3}$. Manuscripts and written sources document mining between 1150 and 1250 A.D. and radiocarbon dates stretch this chronology from the start of the 10 th c. to the late 13th c. For the first time in the 17th c. and a second time in the 18th c., the mines were rediscovered and mining activities were in full swing during the 19th c. before their closure in the early twentieth century owing to exhausted veins (Ancel, 2010, 2012). The archaeological survey, that started in 2003 in the Fressinières valley, uncovered several opencast mines that comprised scrapings on the outcrops, trenches and larger pits (Py and Ancel, 2007; Py, 2010). We have estimated that the extracted ore amounted to a few hundred cubic metres. This small district called Faravel (Faravellum) is explicitly mentioned in 1169 A.D. and a first series of ${ }^{14} \mathrm{C}$ dates situated its


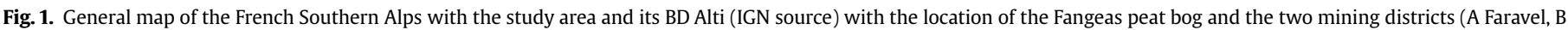
Argentière). 
exploitation between the 10th and the 13th c. (Py and Ancel, 2007; Py et al., 2013). Written sources suggest mining reactivation in the 15th c. (Braunstein, 1986) and archaeological evidence (drill steel holes) attests modern exploration, also attested by texts (Ancel, 2006). To date, written documents and archaeological artefacts have not delivered data prior to the 10th c. for mining activities. However, the presence of small copper deposits in this area (Fangeas sector) and the existence in the near Haut Queyras and the Rousses Massif (Isère) of significant prehistoric mines (Barge, 2006; Bourgarit et al., 2008; Carozza et al., 2010), suggest earlier mining. In order to investigate this question and further define silver-lead mining, we carried out both a geochemical and a palynological study in the upper Freissinières valley using lead and its stable isotopes as markers of mining exploitation (Walsh et al., 2006; Segard, 2009, 200201). In parallel, the pit and extraction shaft of archaeological excavation have revealed timbering, shoring elements and wood fittings that were perfectly preserved (Py, 2010; Burri et al., 2013) (Fig. 3). Their dendrochronological analysis shall be used to refine the chronology of mining activity and shall contribute to characterise the exploited woodland areas. These investigations shall be associated with anthracological analyses of charcoals collected from firesetting (Py et al., 2012) owing to the identified method of fire-cracking used for centuries to fracture very hard rock surfaces and extract silver-lead ores (Py, 2006; Py et al., 2013).

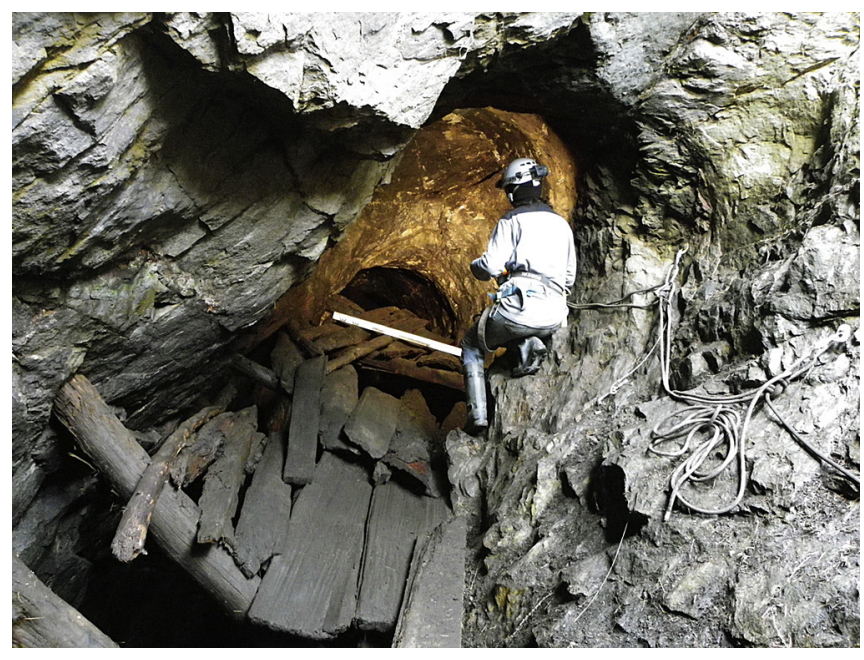

Fig. 3. Medieval wooden floor in a working place (Great Pit, Faravel district).

\subsection{Physical and geological context}

The study area is located in the northern zone of the French Southern Alps, between Embrun and Briançon (Fig. 1). The climate is subject to Mediterranean and mountain influence: it



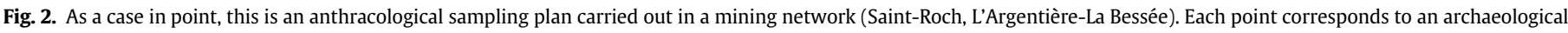
excavation area where samples were carried out. Each group of points corresponds to a well characterised chronological phase of activity. 
is highly contrasted and characterised by low rainfall and a wide range of daily to annual temperatures. The study area embraces two parallel valleys oriented east-west: the Byaisse and the Fournel, both located on the right bank of the Durance River. They are characterised by a dense hydrographical system with glacial lakes and numerous resulting torrents. Both are high altitude valleys sculpted by glacial erosion (trough, rock bar, morainic system). Geologists have identified several mineral deposits (including silver, lead and copper minerals) of which the two main ones are the Argentière and Faravel districts. Both districts were subjected to the mining work cited above. The Argentière (or "Fournel") district is located at the confluence of the small valley of Fournel and the Durance valley in the Briançon area of the Alpine mountains (Fig. 1). Mining excavations were discovered between 1000 and $1500 \mathrm{~m}$ above sea level (asl). From east to west, the terrains comprised Carboniferous coal sandstone, Permian conglomerate, Triassic quartzites and limestones (Ancel et al., 2010). Limestone deposits in the Durance axis and siliceous deposits in the small valley constitute most of the substratum. The landscape is strongly affected by tectonics and dislocated by numerous faults. The ore veins are embanked in quartzites, oriented within northeastsouthwest sections, sub-vertical or tilted towards the southeast panels. These veins were uncovered by erosion owing to deep digging by the torrent over $250 \mathrm{~m}$ within quartzites and limestones. The predominant ore is the silver-bearing galena ( $\mathrm{PbS}$ ) containing $2-3 \%$ silver (Ancel et al., 2010). The Faravel district is spread between 1950 and $2150 \mathrm{~m}$ asl in the southern branch of the Byaisse valley where siliceous substrata are dominant. These later are composed of Quaternary formations that partially overlap sedimentary deposits that include the Champsaur sandstone benches, local limestone nummulites and globigerina marls. The coverage of dolomitic lenticular limestones and spilites is deeply cut by glaciers. It reveals the crystalline basement of the Ecrins massif composed of gneiss and quartz of which numerous veins are visible within the thin sedimentary cover. This geological setting has facilitated the discovery of mineralised veins, which are revealed by their bright colours in the outcrops, and contain argentiferous galena $(\mathrm{PbS})$, blende $(\mathrm{ZnS})$ and chalcopyrite (CuFeS2) (Py and Ancel, 2007).

\subsection{Present vegetation}

The vegetation is terraced and contrasted (Meyer, 1981; Py et al., 2013). Pre-steppe grasslands (Juniperus communis L. subsp. communis, J. sabina L., J. thurifera L., Lavandula vera D.C.) occupy the bottom of the south-facing slopes at the entrance of the small valleys and in the Durance axis. With agrarian abandonment, dense shrub vegetation now grows on the edge of meadows and ancient farming terraces (Berberis vulgaris L., Prunus mahaleb L., Rosa montana Chaix, Ribes uva-crispa L.). Deciduous mesohygrophilous woodland occupies torrent banks, bottom and midheight of north or northeast slopes (Acer pseudoplatanus L., Sorbus aucuparia L., Fraxinus excelsior L.). Larch forest (Larix decidua Mill.) and mountain ash thickets stand on top of ancient grasslands. Fir forest (Abies alba Mill.) mixed with larch in its upper margin grows in the fresh northern slope stations. At the entrance of the small valleys, on the southern slopes, meadows and scrubs change into thermophilic deciduous woodlands (Sorbus aria L., Acer campestre L., Acer opalus Mill., Quercus pubescens Willd. Viburnum lantana L.) and into juniper heathlands (Juniperus communis) in the warmest sites. At higher elevations, these formations are replaced by heliophilous pine forest (Pinus sylvestris L., Pinus uncinata Mill. Mirb Ex.). The subalpine level is characterised mainly by the larch wood pasture in its lower limit and by the larch dominating rhododendron heathland (Rhododendron ferrugineum L., Vaccinium myrtillus L.) in its upper limit. This vertical zonation is crowned by extra-silvatic rhododendron and dwarf juniper heathlands (Juniperus nana Willd.), relayed by Alpine grasslands.

\section{Material and methods}

\subsection{Sites and field sampling}

Geochemical and palynological analyses were carried out on sediment samples from the Fangeas peat bog (Fig. 1), a small wetland (60 $\mathrm{m}$ in its longest axis) situated at $1990 \mathrm{~m}$ asl within a small elliptical closed depression on a grassy bench. Its size facilitates the collection of locally produced pollen that can also originate from distant sources owing to its seasonal exposure to winds from the Durance valley. The peat depth does not exceed $1 \mathrm{~m}$ at the most. A sequence of $83 \mathrm{~cm}$ was taken with a Russian core barrel. It consists of dark beige coarse detritus gyttja at the base, followed by a browner peat from $(83-60 \mathrm{~cm})$ and a fibrous and humified peat ( $30 \mathrm{~cm}$ to the surface). Peat is low in wood macro-remains. Above $34 \mathrm{~cm}$, the sampling was realised every one or two $\mathrm{cm}$ to highlight recent environmental change related to human activity (see Fig. 7).

Lead ores from the two mining districts ore deposits (FaravelArgentière) were also analysed in order to characterise the geochemical imprint of lead deposits and to compare them to the geochemical signatures of atmospheric deposits sealed in peat sediments. These analyses will be used to start a database of ore imprints of the studied area.

Charcoals from firesetting have been sampled in the two afore-mentioned mining districts. Carbonised deposits likely to give anthracological information for the different stages of mining activity were sampled (Fig. 2). The sampling protocol

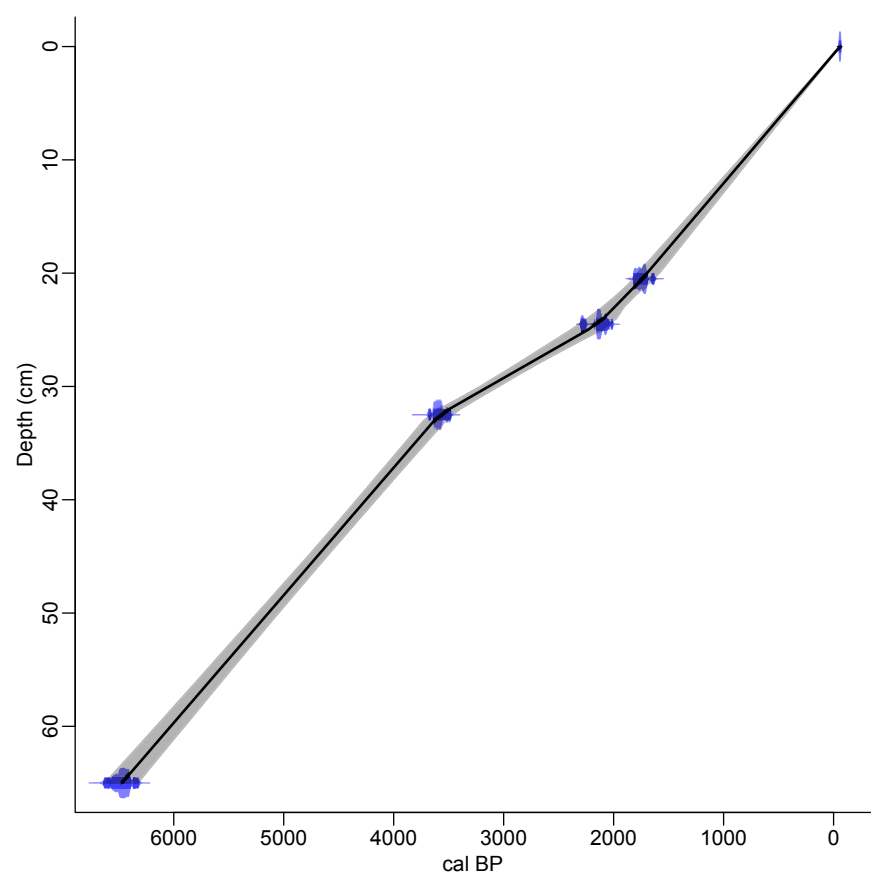

Fig. 4. Age-depth curve for Fangeas based on calibrated radiocarbon dates (cal BP). 


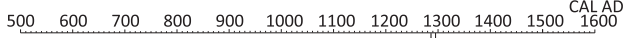

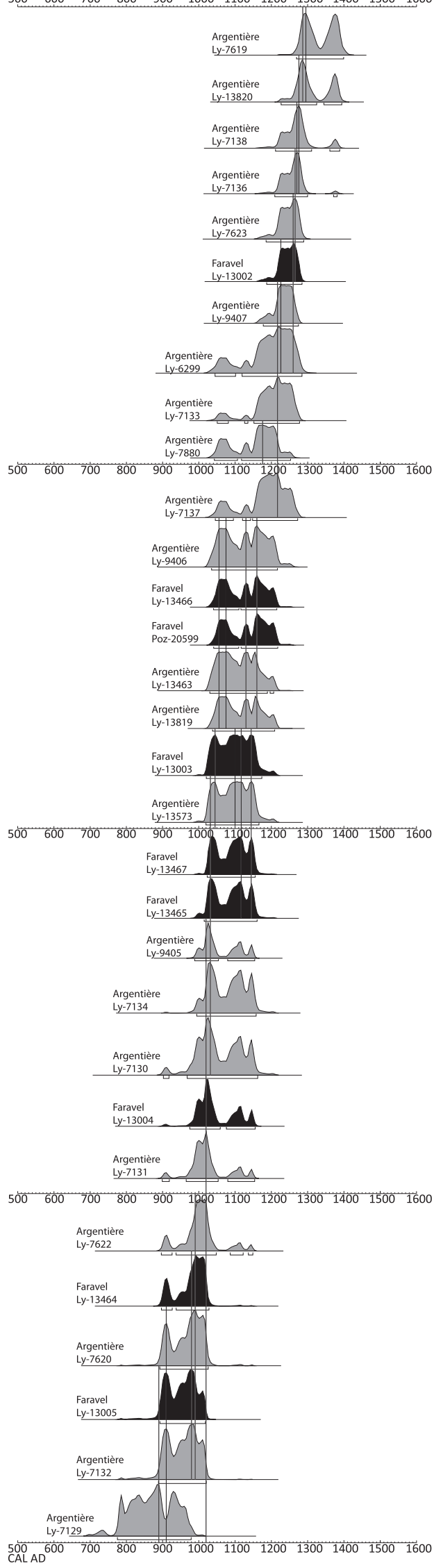

Fig. 5. Probability distributions of ${ }^{14} \mathrm{C}$ dates from the mining districts of Argentière and Faravel (grey histograms show possible ages for the samples from Argentière and black histograms for the samples from Faravel). used is described in Py (2006) and Py et al. (2013). All samples were subjected to flotation in a column of 6 and $4 \mathrm{~mm}$ sieves. The $6 \mathrm{~mm}$ mesh was used to (i) separate off larger stones and prevent charcoal fragmentation and (ii) prevent the finer mesh from getting clogged up. In total, 42 samples were taken from Faravel's backfills and circulation layers (in galleries, wells, pits, trenches, etc.) and 107 from Argentière's five mining networks called Saint-Roch; Combe Blanche; Old Works; Pinée and Lauzebrune (Ancel et al., 2010). In some networks (e.g. in SaintRoch, see Fig. 2), charcoal deposits from the most recent stage of mining activity were sampled in works situated more than $100 \mathrm{~m}$ from the opencast entrances.

Only the Faravel district contains waterlogged wood (Fig. 3). Argentière's wood facilities have disappeared because the mines were not durably submerged. Wooden artefacts studied here, arise from two works: a well (Great Well) and an extraction pit (Great Pit) (Py, 2010). All wood pieces, with or without sapwood, and including a relatively long growth ring series ( $>60$ years) were sampled during excavations carried out in 2005, 2007 and 2008. One to two wood sections were cut in each piece of wood. Some pieces that remained in place (props) were cored. But, resorting to this method was limited because the loss of cellular wall rigidity of waterlogged wood gave poor quality cores (breaking, twisting). In total, 178 wood pieces were sampled. The corpus is composed of: i) pieces from timbering in place (props and floor pieces); ii) wood pieces from timbering or facilities entangled in back-filling of works; iii) small wood pieces and off-cuts included in back-fill.

\subsection{Laboratory methods}

\subsubsection{Radiocarbon dating}

Three peat samples and one wood fragment were sampled from the Fangeas core at $64-65 \mathrm{~cm} ; 32-33 \mathrm{~cm} ; 24-25 \mathrm{~cm}$ and 20-21 cm in depth for AMS radiocarbon dating (Table 1). Charcoal samples from different mining sectors were dated by the liquid scintillation counting method. This conventional method was prioritised since sampled deposits were rich in charcoals (Py et al., 2013). AMS radiocarbon dating was used for only one charcoal fragment from scraping backfill. These samples originated mainly from charcoal (6-10 g per sample) and wood (just one sample) deposits that were excavated by archaeologists in the different mining networks. The choice of the samples for the radiocarbon dating was based on the analysis of the operating dynamic. As a priority, the carbonised deposits from firesetting that were likely to provide information on the different stages of mining activity were selected (Table 2). In total, 24 radiocarbon dates were produced for the Argentière district and 9 for the Faravel district (Table 2 and Py et al., 2013).

Table 1

AMS dates on bulk sediments samples and wood from Fangeas's bog.

\begin{tabular}{llllll}
\hline Commune & $\begin{array}{l}\text { Sample } \\
\text { name }\end{array}$ & $\begin{array}{l}\text { Depth } \\
(\mathrm{cm})\end{array}$ & Lab-code Material $\begin{array}{l}\text { Uncalibrated } \\
\text { date BP }\end{array}$ & $\begin{array}{l}\text { Calibrated } \\
\text { age range } \\
\text { (probability } \\
95.4 \%)\end{array}$ \\
\hline Fressinières Fangeas 1 & $20-21$ & Poz-9739 Peat & $1805 \pm 30$ & $\begin{array}{l}128-323 \\
\text { cal AD }\end{array}$ \\
Fressinières Fangeas 2 & $24-25$ & Poz-9659 Peat & $2140 \pm 30$ & $\begin{array}{l}353-56 \\
\text { cal BC } \\
1737-1530 \\
\text { cal BC } \\
4686-4369 \\
\text { cal BC }\end{array}$ \\
\hline
\end{tabular}


Table 2

${ }^{14} \mathrm{C}$ dates on charcoal and wood samples from mining districts of Argentière and Faravel.

\begin{tabular}{|c|c|c|c|c|c|c|}
\hline District & Area & Sector & Lab. no. & Material & Uncalibrated date BP & Date Cal AD (95.4\% prob.) \\
\hline Argentière & Old works & Working Place “1001 Nights” & Ly-7129 & Charcoal & $1160 \pm 40$ & $775-980$ \\
\hline Argentière & Lauzebrune & Salon (backfill) & Ly-7132 & Charcoal & $1080 \pm 40$ & $889-1022$ \\
\hline Argentière & Old works & Primitive gallery & Ly-7620 & Charcoal & $1065 \pm 40$ & $892-1025$ \\
\hline Argentière & Lauzebrune & “Salon” (filled-up Erbstollen) & Ly-7622 & Charcoal & $1030 \pm 40$ & $895-1150$ \\
\hline Argentière & Old works & Working place "Arch" & Ly-7131 & Charcoal & $1015 \pm 37$ & $899-1154$ \\
\hline Argentière & Old works & Black south gallery & Ly-7130 & Charcoal & $995 \pm 48$ & $901-1163$ \\
\hline Argentière & Old works & Black south gallery & Ly-6296 & Charcoal & $875 \pm 100$ & $977-1292$ \\
\hline Argentière & Old works & Blind level & Ly-9405 & Charcoal & $990 \pm 30$ & $988-1154$ \\
\hline Argentière & Old works & Blind level & Ly-9406 & Charcoal & $895 \pm 40$ & $1035-1217$ \\
\hline Argentière & Lauzebrune & “Salon” (Base) & Ly-7133 & Charcoal & $827 \pm 43$ & $1051-1277$ \\
\hline Argentière & Old works & Blind level & Ly-9407 & Wood & $805 \pm 30$ & $1178-1274$ \\
\hline Argentière & Old works & Entry chamber (soil) & Ly-13820 & Charcoal & $695 \pm 45$ & $1225-1394$ \\
\hline Argentière & Old works & Superior Gallery “1001 Nights” & Ly-6297 & Charcoal & $621 \pm 94$ & $1221-1447$ \\
\hline Argentière & Old works & Fault-line scarp “1001 Nights” & Ly-7619 & Charcoal & $665 \pm 45$ & $1270-1398$ \\
\hline Argentière & Saint-Roch & Large superior working place & Ly-7134 & Charcoal & $975 \pm 40$ & $993-1158$ \\
\hline Argentière & Pinée & Network of shafts & Ly-13573 & Charcoal & $945 \pm 35$ & $1020-1165$ \\
\hline Argentière & Pinée & Base gallery & Ly-13819 & Charcoal & $905 \pm 30$ & $1038-1208$ \\
\hline Argentière & Combe Blanche & Gallery of the channel (soil) & Ly-13463 & Charcoal & $915 \pm 35$ & $1030-1207$ \\
\hline Argentière & Combe Blanche & Raising of airing & Ly-7137 & Charcoal & $845 \pm 45$ & $1045-1271$ \\
\hline Argentière & Saint-Roch & Low chamber & Ly-6299 & Charcoal & $820 \pm 60$ & $1044-1284$ \\
\hline Argentière & Saint-Roch & Gallery of skidding & Ly-7880 & Charcoal & $872 \pm 36$ & $1042-1253$ \\
\hline Argentière & Saint-Roch & Twin working place & Ly-7623 & Charcoal & $770 \pm 40$ & $1185-1289$ \\
\hline Argentière & Saint-Roch & Decreased working place & Ly-7136 & Charcoal & $750 \pm 40$ & $1210-1380$ \\
\hline Argentière & Combe Blanche & Large vertical working place & Ly-7138 & Charcoal & $735 \pm 45$ & $1211-1397$ \\
\hline Faravel & Fangeas-II & Great pit (gallery) & Ly-13466 & Charcoal & $895 \pm 30$ & $1040-1215$ \\
\hline Faravel & Fangeas-II & Great pit (entry) & Ly-13467 & Charcoal & $955 \pm 30$ & $1022-1155$ \\
\hline Faravel & Fangeas-I & Great well & Ly-13465 & Charcoal & $966 \pm 35$ & $1014-1160$ \\
\hline Faravel & Fangeas-I & Great well (search) & Ly-13464 & Charcoal & $1055 \pm 35$ & 895-1027 \\
\hline Faravel & Faravel-I & Gallery 3 & Ly-13002 & Charcoal & $780 \pm 35$ & $1186-1284$ \\
\hline Faravel & Faravel-I & West pit & Ly-13003 & Charcoal & $940 \pm 35$ & $1021-1173$ \\
\hline Faravel & Faravel-I & West pit & Ly-13004 & Charcoal & $1000 \pm 35$ & $975-1155$ \\
\hline Faravel & Faravel-II & Fire level & Ly-13005 & Charcoal & $1085 \pm 35$ & $892-1018$ \\
\hline Faravel & Faravel-I & Amont trench & Poz-20599 & Charcoal & $890 \pm 30$ & $1041-1217$ \\
\hline
\end{tabular}

All dates have been calibrated against the IntCal09 data set (Reimer et al., 2009) using the program Oxcal v4.2.2 (Bronk Ramsey, 2009).

\subsubsection{Anthracology}

Charcoals were identified using reflected light microscopy with magnifications at 100, 200 and 500 times. The observation was performed on the three anatomical planes (transversal, radial and tangential) obtained by simple hand fractures. These planes were compared with data from xylology atlases (Greguss, 1955, 1959; Schweingruber, 1978, 1990; Vernet et al., 2001), specialised journals (Anagnost et al., 1994; Talon, 1997) as well as LA3M, IMBE and CBAE's current wood reference collections. The level of accuracy when identifying taxa is either: the species (e.g. A. alba), or a group of anatomically indistinct species (e.g. L. decidua/Picea abies), or the genus (e.g. Alnus), or the family (e.g. Fabaceae), or the sub-family (e.g. Rosaceae, Maloideae). The presence of compression wood (microfibrils in tracheids) was systematically recorded. The fragments with compression wood were counted (Py et al., 2013). The curvature of the growth rings was evaluated observing the shape of the ring boundaries (curved, intermediate, straight) (Marguerie and Hunot, 2007). In addition, the minimum initial diameter of a series of fragments, which clearly originate from small branches or juvenile stems, was restored through the use of a target printed on a transparency.

\subsubsection{Dendrochronology and dendrology}

Before dendrochronological analysis, the wood sections were identified. As for anthracological analysis, determination is based on microscopic observation of the three anatomical planes (see above): tiny wood chips are removed using a razor blade, mounted between a slide and slip cover and observed under a transmitted light microscope. The dendrochronological method is well documented (Schweingruber, 1988; Lambert, 1998; Edouard and Thomas, 2008; Delwaide and Filion, 2010). Here, the wood, nearly exclusively coniferous, was treated in two ways: certain sections were dried and polished but the majority was kept moist and plane surfaces were created along the radii with a razor blade. Tree rings observation and measuring were performed with a binocular magnifier. After identifying and pointing, growth rings were measured (in 1/100 $\mathrm{mm}$ ) with the Lintab tester and TSAP software "Tree ring series Analysis Programme" (Programme Rinntech 2003). Time series obtained were previously standardized using the E index Besançon (Lambert, 1998; Lambert, 2006) and the corridor method (Lambert, 2006, 2011; Lambert et al., 2010). Their comparison is based on the correlation coefficient calculation together with a confidence level. All arithmetic operations (standardization, synchronization and dating, chronological assembly) were performed with the integrated software Dendron IV (Lambert, 2011). Synchronism positions were verified by visual comparison of ring width curves. Synchronized chronologies were combined to build representative average group chronologies. On the basis of local and regional existing chronologies (Serre, 1978; Tessier, 1986; Corona et al., 2010, 2011; Edouard, 2010a, 2010b), these groups were dated absolutely. Dating the death of the tree or its felling is specified by the presence of sapwood and cambium indicating the last ring. Wood is put to use in the mine shortly after felling. The timber is placed preferably green because it offers greater resistance to buckling efforts exerted by the rock (Maggiori, 2001). Therefore, the felling date corresponds to the implementation of the wood in the mine when re-use has not occurred. If sapwood is 


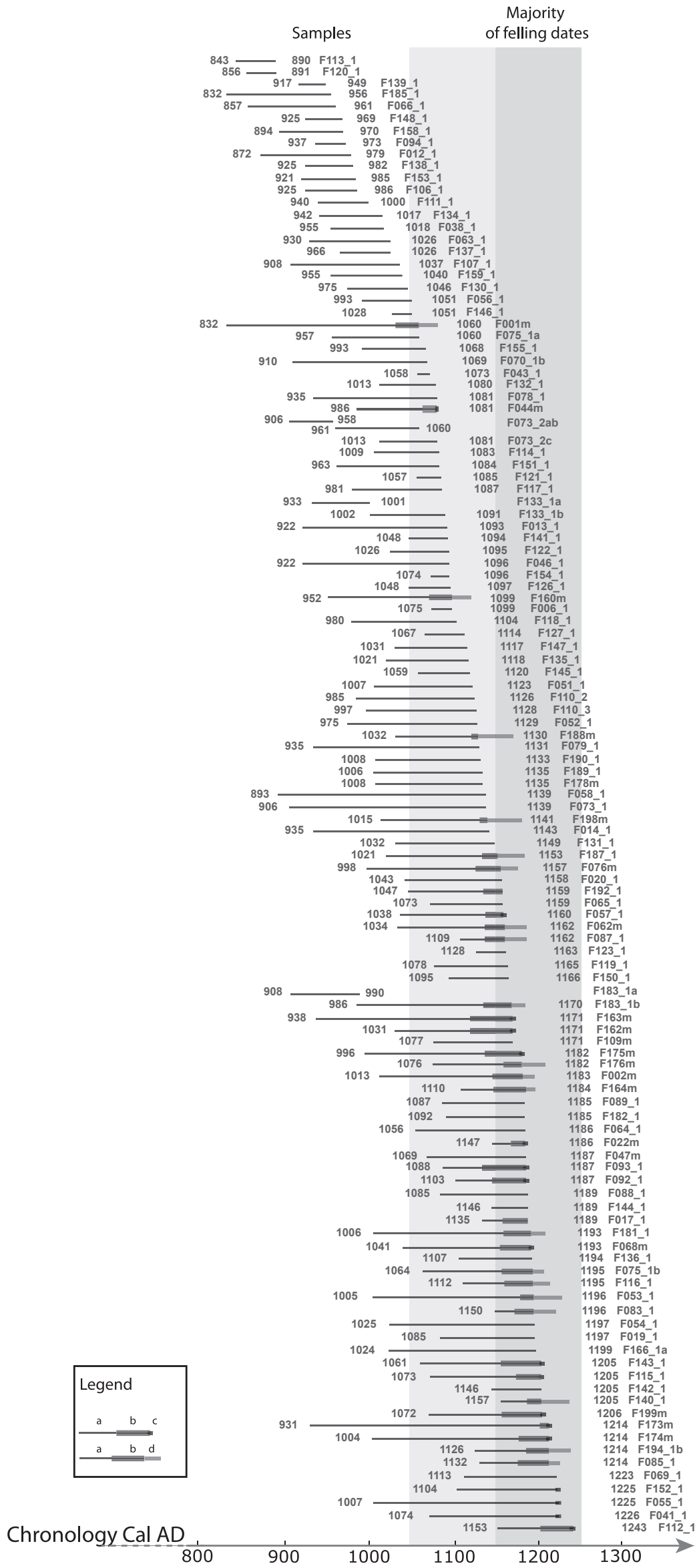


sapwood and maximum sapwood with $95 \%$. 







present but eroded (last ring or rings not present), a felling date is estimated, with a few years' uncertainty. The calculation of the maximum number of sapwood rings for a given species (larch/ spruce in this case) provides a range of years for which the probability of tree death within such period is high (Lambert, 2006). The average number of sapwood rings, based on 338 larches/spruces of various ages, is $32 \pm 9$ rings. The maximum number of sapwood rings is 50 (2 standard deviations) with a confidence level of $95 \%$. Interval discussion is possible by comparing the characteristics of the analysed wood (shape, condition, degree of erosion, shaping of the trunk, width of the last rings). When the pith and the last ring are kept, ring sequences give an indication of the age of the tree. Growth patterns are also indicators of growing conditions (e.g. sites, forest density, parasite infections). Observation of morphotechnical features and ring-curvature radius has, in some cases, enabled the minimum initial diameter of a trunk or branch to be estimated.

\subsubsection{Palynology and geochemistry}

Pollen extraction was performed using acid digestion (HCl-HF) and acetolysis (Erdtman, 1954; Overbeck, 1958). Pollen identification was performed using the IMBE's pollen reference collection and the pollen atlases of Europe and North Africa (Reille, 1992, $1995,1998)$. The pollen percentages are based on a pollen sum (more than 400 grains) excluding Cyperaceae. The pollen tables are stored and available on the E.P.D. (www.europeanpollendatabase. net).

We have measured lead ( $\mathrm{Pb})$, its stable isotopes and Aluminum (Al) in sediments from the Fangeas peat. $\mathrm{Al}$ is a well-known tracer of crustal abundances used for estimating the relative contribution of rock-derived $\mathrm{Pb}$ using "Crustal Enrichment Factors" (EFs). EFs are used to better discriminate between anthropogenic and natural contributions of particulate $\mathrm{Pb}$ accumulated in the atmosphere and sediments (Duce et al., 1976; Woitke et al., 2003; Selvaraj et al., 2004; Abrahim and Parker, 2008). EFs correspond to the ratio of $\mathrm{Pb}$ versus a well-known crustal originating element such as $\mathrm{Al}$. Here, EFs are chosen as the ratio of $\mathrm{Pb} / \mathrm{Al}$ in each sample to that of the crustal $\mathrm{Pb} / \mathrm{Al}$ ratio measured at $80 \mathrm{~cm}$ within the core (older than 5680 years BP), where no anthropogenic influence is expected. Results are shown in Table 3 and Fig. 8. Because of uncertainties on

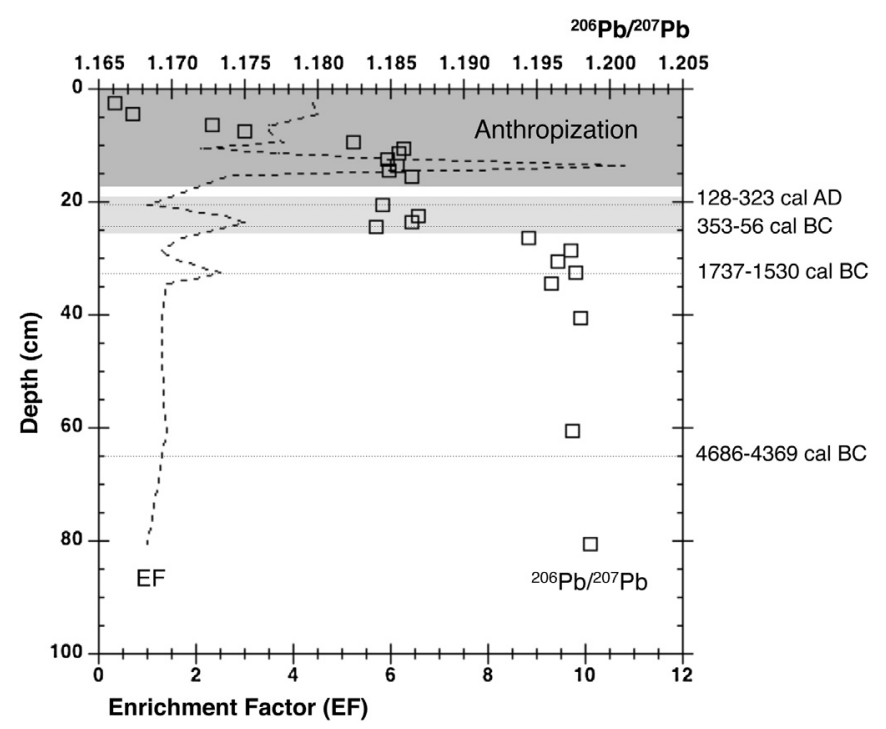

Fig. 8. Variation of ${ }^{206} \mathrm{~Pb} /{ }^{207} \mathrm{~Pb}$ isotopic ratios and crustal Enrichment Factors (EFs) with depth in the Fangeas peat core. The calculation of EFs is presented in the method section. the choice of the background $\mathrm{Pb} / \mathrm{Al}$ ratio, it is reasonable to assume that only EFs $>2-3$ may be indicative of another $\mathrm{Pb}$ source rather than crustal to the sample. Preparation of peat material for $\mathrm{Pb}$ and $\mathrm{Al}$ analyses were performed at CEREGE in a HEPA (class 1000) filtered trace metal clean laboratory. About 10-20 mg of sediment was digested using concentrated $\mathrm{HCl}, \mathrm{HNO} 3$ and $\mathrm{HF}$ acids. A fraction of digested material was analysed for $\mathrm{Pb}$ and $\mathrm{Al}$ concentration by Inductively Coupled Plasma Atomic Emission Spectrometry (ICPAES, Join Yvon Ultima C, CEREGE). The uncertainties on $\mathrm{Pb}$ and $\mathrm{Al}$ concentration were generally $<5 \%$. Reproducibility and accuracy for our ICP-AES have been determined in several occasions for major and trace elements (Germanique, 1994; Ollivier et al., 2010). Procedure and analytical blanks were below detection limits. The remaining oxidized fraction was purified on an AG1X8 anionic resin for the determination of the stable $\mathrm{Pb}$ isotopes ratios $\left({ }^{206} \mathrm{~Pb} /{ }^{207} \mathrm{~Pb}\right.$, ${ }^{206} \mathrm{~Pb} /{ }^{204} \mathrm{~Pb}$ and ${ }^{207} \mathrm{~Pb} /{ }^{204} \mathrm{~Pb}$ ) by Thermo-Ionization Mass Spectrometry (TIMS, Finnigan MAT 262, CEREGE). Analytical mass discrimination was corrected using concurrent and repeated analyses of a common $\mathrm{Pb}$ standard reference material SRM981 from the National Institute of Standard and Technology (NIST). Standard deviation did not exceed $0.02 \%$ for ${ }^{206} \mathrm{~Pb} /{ }^{207} \mathrm{~Pb}$ ratios and $0.2 \%$ for ${ }^{206} \mathrm{~Pb} /{ }^{204} \mathrm{~Pb}$ and ${ }^{207} \mathrm{~Pb} /{ }^{204} \mathrm{~Pb}$ ratios.

Table 3

Variation of $\mathrm{Pb}$ isotope ratios and crustal Enrichment Factors (EF) with depth in Fangeas peat core. EF calculations are defined in the method section.

\begin{tabular}{llllll}
\hline Depth $(\mathrm{cm})$ & Date cal. yrs & $\mathrm{Pb}(\mathrm{ppm})$ & $\mathrm{Al}(\mathrm{ppm})$ & $\mathrm{EF}$ & ${ }^{206} \mathrm{~Pb} /{ }^{207} \mathrm{~Pb}$ \\
\hline $2-3$ & & 22.34 & 9132 & 4.4 & 1.1661 \\
$4-5$ & & 19.31 & 7712 & 4.5 & 1.1673 \\
$6-7$ & $1800-1900 \mathrm{AD}$ & 18.33 & 9406 & 3.5 & 1.1728 \\
$7-8$ & & 15.40 & 7917 & 3.5 & 1.1750 \\
$9-10$ & $900-1000 \mathrm{AD}$ & 18.63 & 8946 & 3.8 & 1.1825 \\
$10-11$ & & 16.21 & 13986 & 2.1 & 1.1859 \\
$11-12$ & & 18.49 & 8957 & 3.7 & 1.1856 \\
$12-13$ & & 22.42 & 6706 & 6.1 & 1.1848 \\
$13-14$ & & 23.76 & 3998 & 11 & 1.1854 \\
$14-15$ & & 23.16 & 5903 & 7.1 & 1.1849 \\
$15-16$ & & 12.63 & 8907 & 2.6 & 1.1865 \\
$20-21$ & $128-323 \mathrm{AD}$ & 7.10 & 13265 & 1.0 & 1.1844 \\
$22-23$ & & 8.60 & 6017 & 2.6 & 1.1869 \\
$23-24$ & & 8.95 & 5450 & 3.0 & 1.1865 \\
$24-25$ & $353-56 \mathrm{BC}$ & 6.05 & 4170 & 2.6 & 1.1840 \\
$26-27$ & & 7.96 & 8725 & 1.7 & 1.1945 \\
$28-29$ & & 7.16 & 9761 & 1.3 & 1.1973 \\
$30-31$ & & 6.24 & 6477 & 1.7 & 1.1965 \\
$32-33$ & $1737-1530 \mathrm{BC}$ & 8.01 & 5807 & 2.5 & 1.1977 \\
$34-35$ & & 6.17 & 7831 & 1.4 & 1.1960 \\
$40-41$ & & 8.87 & 12263 & 1.3 & 1.1980 \\
$60-61$ & & 9.52 & 12519 & 1.4 & 1.1975 \\
65 & & nd & nd & nd & nd \\
$80-81$ & & 10.82 & 19590 & 1.0 & 1.1987 \\
\hline
\end{tabular}

\section{Results}

\subsection{Chronology}

\subsubsection{Radiocarbon dating}

AMS dates of the Fangeas core mark the Neolithic $(-65 \mathrm{~cm})$, the Bronze Age $(-35 \mathrm{~cm})$, the middle of the Iron Age $(-28 \mathrm{~cm})$ and the second and third centuries A.D. $(-20 \mathrm{~cm})$, i.e. the Roman period (Table 1 ). Thus, the following periods are not precisely dated, but geochemical and archaeological data are used to make solid assumptions on the location in the core of medieval and post-medieval sequences (see below). The age-depth model 
shows a steady growth of the Fangeas sediment, except between 1737-1530 cal B.C. and 353-56 cal B.C. (3400-2200 cal B.P.) (Fig. 4). These periods reflect a deceleration of peat accumulation.

All radiocarbon dates are presented in Table 2 and in a graph where confidence intervals (95.4\%) and probability peaks are compared (Fig. 5). Two dates with a margin of error greater than \pm 60 years have not been included. This graph represents the main chronological phases of mining activity in the two districts. The black lines connecting the peaks indicate them. Thus, the chronology ranges from the beginning of the 10th c. to the late 13th c. In detail, exploration works started in both districts during the 10 th c. or a little before. Mining activity was active and productive in the late 10th and 11th centuries. It continued to develop throughout the 12th and 13th centuries with new explorations but also probably with periods of standstill or low activity, especially in Argentière's deep excavations. Archaeological and historical data assume that mining finally stopped at the end of the 13th c. but an unsuccessful exploitation attempt during the 14 th c. is not excluded.

\subsubsection{Dendrochronological data}

In total, 178 sections were identified: 154 L. decidua/P. abies, 20 Pinus cembra, 1 Pinus type sylvestris and 3 deciduous trees ( $c f$. Rosaceae, Maloideae). There is an anatomic uncertainty between the larch and spruce wood expressed by the taxon $L$. decidua/P. abies (Schweingruber, 1990; Talon, 1997). However, biogeographical, ecological and regional palaeological data (e.g. Ali et al., 2005; Talon, 2010; Touflan et al., 2010) argue for the unique presence of larch.

A total of 149 sections were dendrochronologically analysed: 131 larches, 16 arolla pines, 1 Scots pine type and 1 deciduous tree. 131 sections of larch provided sequences from 23 to 284 rings. 59 sections have sequences of more than 100 rings. 16 sections of arolla pine have sequences from 23 to 218 rings and only 4 of them have more than 100 rings. Approximately two thirds of dated wood are off-cuts or fragments of wood because they give quite long ring series, sufficiently characteristic to be dated. In addition, the sapwood has been preserved in certain fragments. In contributing to the construction of a strongly replicated local chronology and offering valuable additional felling dates, more has been learnt about mining activities. This enabled 118 larches to be dated. A total of 38 sections with complete sapwood (27) or partially preserved (11) consequently provide a felling date that is accurate to the nearest year, or estimated on the basis of maximum sapwood calculation. Only 3 synchronous arolla pines were dated; the other 4 have a significant synchronism with the dated group, but this remains to be confirmed. 9 pieces of wood have not been dated. The larch chronology covers a period from 777 to 1243 , i.e. 467 years (Fig. 6). 3 dated arolla pines are contemporary and provide a chronology of 220 years, covering the period from 1007 to 1226 . The last ring is preserved for 30 dated wood specimens ( 27 larches and 3 arolla pines) and their felling date is estimated between 1081 and 1243. Estimated felling dates for another 11 larch sections range between 1060-1082 and 1205-1238. Felling dates, to the nearest or estimated year, therefore range between 1060 A.D. and 1243 A.D., between the second half of the 11th c. and the first half of the 13th c. The majority of felling dates are concentrated over a century, between the second half of the 12th c. and the first half of the 13th c. Within this period, date distribution highlights six felling phases (Fig. 6). Three phases are poorly represented: i) the second half of the 11th c. (after 1060 and around 1080), ii) up to 1160 (there is only one piece of wood with sapwood and a felling date - maximum interval - between 1099 and 1122), iii) midthirteenth century (because there is a felling date in 1243). Three other phases are well represented: two during the second half of the 12th c. (1150-1170 and 1180-1195) and the first two decades of the 13th c. (1205-1214).

\subsection{Pollen zones}

The diagram was sequenced in seven pollen assemblage zones (Fig. 7) (Walsh et al., 2006; Segard, 2009). Contrary to Cushing (1967), we consider that the limit between two homogeneous pollen zones must be between two spectra: the first belonging to the lower zone and the second to the upper zone.

Zone 1 (from 83 to $27 \mathrm{~cm}$ ) covers the Neolithic, Chalcolithic, Bronze Age, Hallstatt and the first half of La Tène. It is characterised by very high frequencies of arboreal pollen dominated by Pinus (pine). A P. cembra (arolla pine) pollen curve is proposed, but the identification of arolla pine pollen is possible only with very well preserved grains. Therefore, percentages recorded in the diagram heavily underestimate the role of this species that should be dominant in the vicinity. The continuous curves of Abies (fir) and Quercus (oak) reflect a steady influx of pollen from trees located at lower altitudes. The continuous curve of Betula (birch) pollen indicates a contribution from azonal thickets (bogs and open woodlands). Cyperaceae, reflecting the mire vegetation, dominate the nonarboreal pollen together with few herbaceous taxa from grasslands and rocky slopes (mentioned as ruderal-steppe, such as Artemisia, Centaurea, Chenopods, Compositeae, Helianthemum). At the end of this zone, from $40 \mathrm{~cm}$, an outbreak of the continuous Larix (larch) curve as well as a slight reduction of tree percentages in favour of Poaceae are noticeable. These changes are associated with declining frequencies of birch. The Fagus (beech) curve start is consistent with its modest regional expansion observed in sites of lower altitude (Beaulieu, 1977; Brugiapaglia et al., 1998; Kharbouch, 2000; Walsh et al., 2014).

Zone $2(26-24 \mathrm{~cm})$ is marked by a reduction in the AP/NAP ratio and the sharp drop of the pine curve to $<50 \%$. These changes are slightly posterior to $360-50$ cal B.C. and preceded by the first appearance of cereal pollen grains. Moreover, they are associated with a peak of Cyperaceae (40\%), Rumex, ruderal-steppe taxa and Poaceae. Alnus (alder) and Alnus viridis (green alder) become more abundant and the decline of the arolla pine curve begins. Larch and fir frequencies reach their maximum and beech remains stable.

Zone $3(23-21 \mathrm{~cm})$ is marked by a recovery of all pines, a decrease in larch and fir curves and modest beech presence. The higher frequency of AP/NAP ratio is associated with the decline of Poaceae, ruderal-steppe taxa, Rumex and Cyperaceae curves and a clear increase of herbaceous grassland pollen. Zones 2 and 3 cover the majority of La Tène and the early centuries of our era. The boundary between zones 3 and 4 is dated to 120-330 cal A.D.

Zone $4(20-12 \mathrm{~cm})$ is characterised by a major increase of Poaceae and, to a lesser extent, plantains (Plantago pp. and a moderate amount of Plantago lanceolata). These changes are associated with a decline in pines that reach their lowest level towards the end of the zone. Oak and fir curves become very fragmented while larch remains stable despite two significant drops. Juglans (walnut) and Castanea (chestnut) appear and cereal grains presence intensifies. Ruderal-steppe taxa, herbaceous grassland and Cyperaceae curves sharply decrease.

Zone $5(11-7 \mathrm{~cm})$ is characterised by the near disappearance of arolla pine and larch and the expansion of Cyperaceae. Ranunculaceae and Rumex increase and high rates of plantains persist. The frequencies of herbaceous grassland and ruderal-steppe taxa are higher or equal to $10 \%$. Cereal presence becomes continuous.

Zone 6 corresponds to 3 spectra $(6,5$ and $4 \mathrm{~cm})$ marked by a maximum of pollen from cultivated lowland trees (Olea and walnut). Plantains and grassland species remain at a high level. The 
herbaceous grassland and ruderal-steppe taxa decrease while Rumex and cereals remain stable.

Zone 7 ( $3 \mathrm{~cm}$ and the surface) shows the maintenance of pine frequencies $>50 \%$ and the sharp decline of nonarboreal pollen. Cereal and walnut frequencies are very low, while Olea (olive) frequencies persist. Alder remains relatively high.

\subsection{Geochemistry data}

$\mathrm{Pb}$ is an efficient anthropogenic marker to establish past and present human activities. It was amongst the first metals to be refined and used owing to its low melting temperature, its malleability and its resistance to corrosion (Nriagu, 1983). The oldest $\mathrm{Pb}$ artifacts are dated to 8000 years ago in Anatolia and $\mathrm{Pb}$ has been extensively mined since then to produce many artefacts (see references in Lucas and Harris, 1962; Nriagu, 1983). Its stable isotopes, ${ }^{204} \mathrm{~Pb},{ }^{206} \mathrm{~Pb},{ }^{207} \mathrm{~Pb},{ }^{208} \mathrm{~Pb}$ of which the last three are endmembers of the Uranium (U)-Thorium (Th) decay chains, are used to characterise pollutant $\mathrm{Pb}$ (most particularly $\mathrm{Pb}$ ore mining activities) depending on the age and the initial $\mathrm{U}-\mathrm{Th}$ content of primary geological reservoirs (Doe, 1970). Consequently, ratios of $\mathrm{Pb}$ isotopes will vary according to the origin of $\mathrm{Pb}$ ores, used to manufacture metal artefacts (see references in Brill and Wampler, 1967; Gale and Stos-Gale, 1982, 2000; Stos-Gale and Gale, 1982, 2009; Stos-Gale et al., 1996). These isotopic imprints can be used to reconstruct ancient human activities recorded in continental reservoirs, such as peatbogs and lacustrine sediments (see references in Shirahata et al., 1980; Renberg et al., 1994; Shotyk et al., 1998; Thevenon et al., 2011; Martinez Cortizas et al., 2012).

$\mathrm{Pb}$ concentrations measured in Fangeas peat sediments show two main trends with rather uniform values at $80-20 \mathrm{~cm} \mathrm{(5-}$ $11 \mathrm{ppm}$ ) and a significant increase between $15 \mathrm{~cm}$ and the surface (13-24 ppm) (Table 3). The shift at $15 \mathrm{~cm}$ could result from an increase in mining and/or other industrial activities. Meanwhile, concentration changes also depend on crustal abundances, and therefore concentration alone cannot be decisive to unquestionably indicate the environmental impact of mining activities, mostly with $\mathrm{Pb}$ concentrations that vary within the well-known range of natural crustal abundances (i.e. Mc Lennan, 1995; Wedepohl, 1995). EFs in the deep core $(80-25 \mathrm{~cm})$ are less than 2 , with the exception of a slight increase at 32-31 cm where it reaches 2.6 (Table 3). Above $25 \mathrm{~cm}$, EFs are always $>2$, except at $21-20 \mathrm{~cm}(\mathrm{EF}=1)$, where maxima at $15-12 \mathrm{~cm}(\mathrm{EFs}=6-11)$. EFs calculation corroborate a possible non-crustal contribution to $\mathrm{Pb}$ concentration measured at $15 \mathrm{~cm}$ and above, and suggest an earlier contamination starting at $25 \mathrm{~cm}$ (353-56 cal B.C.) (Fig. 8). In order to confirm such contamination and to disclose the possible origin of the pollutant $\mathrm{Pb}$ accumulated at $25 \mathrm{~cm}$ and above, we use the ratios of stable $\mathrm{Pb}$ isotopes. We present the ratio of ${ }^{206} \mathrm{~Pb}$ to ${ }^{207} \mathrm{~Pb}$ isotopes that are the most accurate $\mathrm{Pb}$ isotope ratios for characterising anthropogenic imprints. ${ }^{206} \mathrm{~Pb} /{ }^{207} \mathrm{~Pb}$ ratio differences as low as 0.002 can be interpreted as geochemically significant in sediment cores (Chow et al., 1973; Shirahata et al., 1980; Ng and Patterson, 1982; Ferrand et al., 1999; Marcantonio et al., 2002; Angelidis et al., 2011). The ${ }^{206} \mathrm{~Pb} /{ }^{207} \mathrm{~Pb}$ ratios show a likely non-contaminated background level at $80-25 \mathrm{~cm}$ $\left(1.199<{ }^{206} \mathrm{~Pb} /{ }^{207} \mathrm{~Pb}<1.195\right)$ and a contaminated level above $25 \mathrm{~cm}$ (Table 3, Fig. 8). The contaminated level displays two trends at $25-10 \mathrm{~cm}\left(1.183<{ }^{206} \mathrm{~Pb} /{ }^{207} \mathrm{~Pb}<1.187\right)$ and above $\left(1.166<{ }^{206} \mathrm{~Pb} /{ }^{207} \mathrm{~Pb}<1.173\right)$ (Table 3$)$. These results confirm the input of an unknown Pb source as early 353-56 cal B.C. within the Fangeas core.

This foreign imprint can be better characterised with the combination of $\mathrm{Pb}$ concentration $\left(1 / \mathrm{Pb}\right.$ ratios) and ${ }^{206} \mathrm{~Pb} /{ }^{207} \mathrm{~Pb}$ ratios, used to differentiate various $\mathrm{Pb}$ clusters and to connect

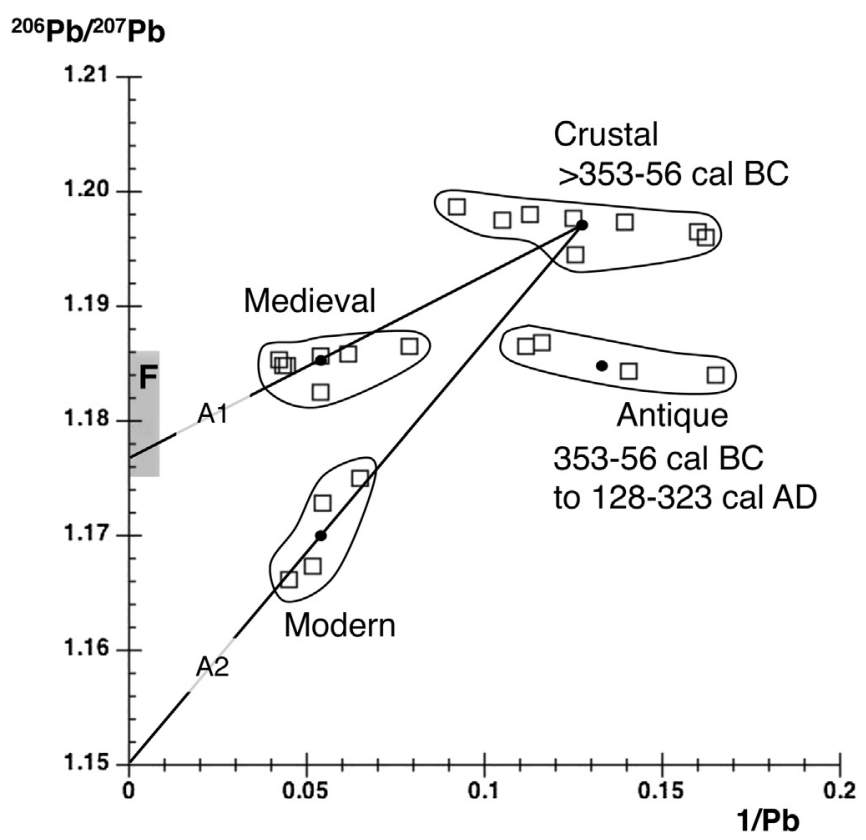

Fig. 9. ${ }^{206} \mathrm{~Pb} /{ }^{207} \mathrm{~Pb}$ versus $1 / \mathrm{Pb}$ in sediment fractions from the Fangeas peat core Clusters are defined according to various periods. A1 and A2 are mixing lanes between these clusters. F corresponds to the range of measured isotopic imprints for lead and copper ores from the Argentière and Faravel mining districts respectively.

them to source imprints (Fig. 9). Pb isotopic imprints of ore samples from Faravel and Argentière's mining remnants $\left(1.175<{ }^{206} \mathrm{~Pb} /{ }^{207} \mathrm{~Pb}<1.186\right)$ are also shown in Fig. 9 where four $\mathrm{Pb}$ clusters can be identified that include a non-contaminated cluster at $80-25 \mathrm{~cm}$ (older than 353-56 cal B.C.), and three contaminated clusters at $25-20 \mathrm{~cm}$ (sequence dated 353-



Fig. 10. ${ }^{206} \mathrm{~Pb} /{ }^{204} \mathrm{~Pb}$ vs. ${ }^{207} \mathrm{~Pb} /{ }^{204} \mathrm{~Pb}$ isotope imprints in sediment fractions from Fangeas peat core. The mean standard deviation (sd) is shown within the plot for ${ }^{206} \mathrm{~Pb} /{ }^{204} \mathrm{~Pb}$ and ${ }^{207} \mathrm{~Pb} /{ }^{204} \mathrm{~Pb}$ ratios. Arrows connect potential source imprints to the isotopic ratios measured in the Fangeas peat (black squares). 
56 cal B.C. $-128-323$ cal A.D.), at $16-10 \mathrm{~cm}$ (probably Middle Ages), and above (Modern and Contemporary periods). The last two can be connected along linear trends of which intersect with the " $\mathrm{y}$ " axis for $1 / \mathrm{Pb}=0$ corresponds to pollutant $\mathrm{Pb}$ source imprints in sediments (Fig. 9; Alleman et al., 2000; Angelidis et al., 2011). We distinguish two mixing lanes, A1 and A2, between the "Crustal" imprint and the "Medieval" and the "Modern" signatures respectively (Fig. 9). The ${ }^{206} \mathrm{~Pb} /{ }^{207} \mathrm{~Pb}$ pollutant imprint determined from A1 $(1.177 \pm 0.004)$ fits the signature of the local $\mathrm{Pb}$ ores $(\mathrm{F}$ imprint; Fig. 9) suggesting the impact of the ore source to explain the foreign $\mathrm{Pb}$ imprint measured within the Fangeas peat during the Medieval period. The ${ }^{206} \mathrm{~Pb} /{ }^{207} \mathrm{~Pb}$ ratio of the pollutant imprint associated with the mixing lane A2 $(1.150 \pm 0.005)$ is consistent with the range of calculated and measured $\mathrm{Pb}$ isotope signatures in France within the past 100 years. During this time, two-thirds of pollutant $\mathrm{Pb}$ was deposited owing to increasing industrial emissions and the use of leaded petrol (Hopper et al., 1991; Deboudt et al., 1999; Véron et al., 1999; Bollhöfer and Rosman, 2001; Flament et al., 2002). Unfortunately, the foreign Pb imprint identified during the Antique periods does not clearly fit the A1 and A2 mixing lanes and therefore cannot be assigned a specific ore imprint.

In order to better discriminate $\mathrm{Pb}$ imprints, we have distinguished the isotopic imprint of the Argentière and Faravel mining districts within a ${ }^{206} \mathrm{~Pb} /{ }^{204} \mathrm{~Pb}$ vs. ${ }^{207} \mathrm{~Pb} /{ }^{204} \mathrm{~Pb}$ isotope plot (Fig. 10). Fangeas sector is within the Faravel district that may be characterised by early copper mining while Argentière is essentially $\mathrm{a} \mathrm{Pb}$ ore district that was exploited during the Middle Ages, Modern and

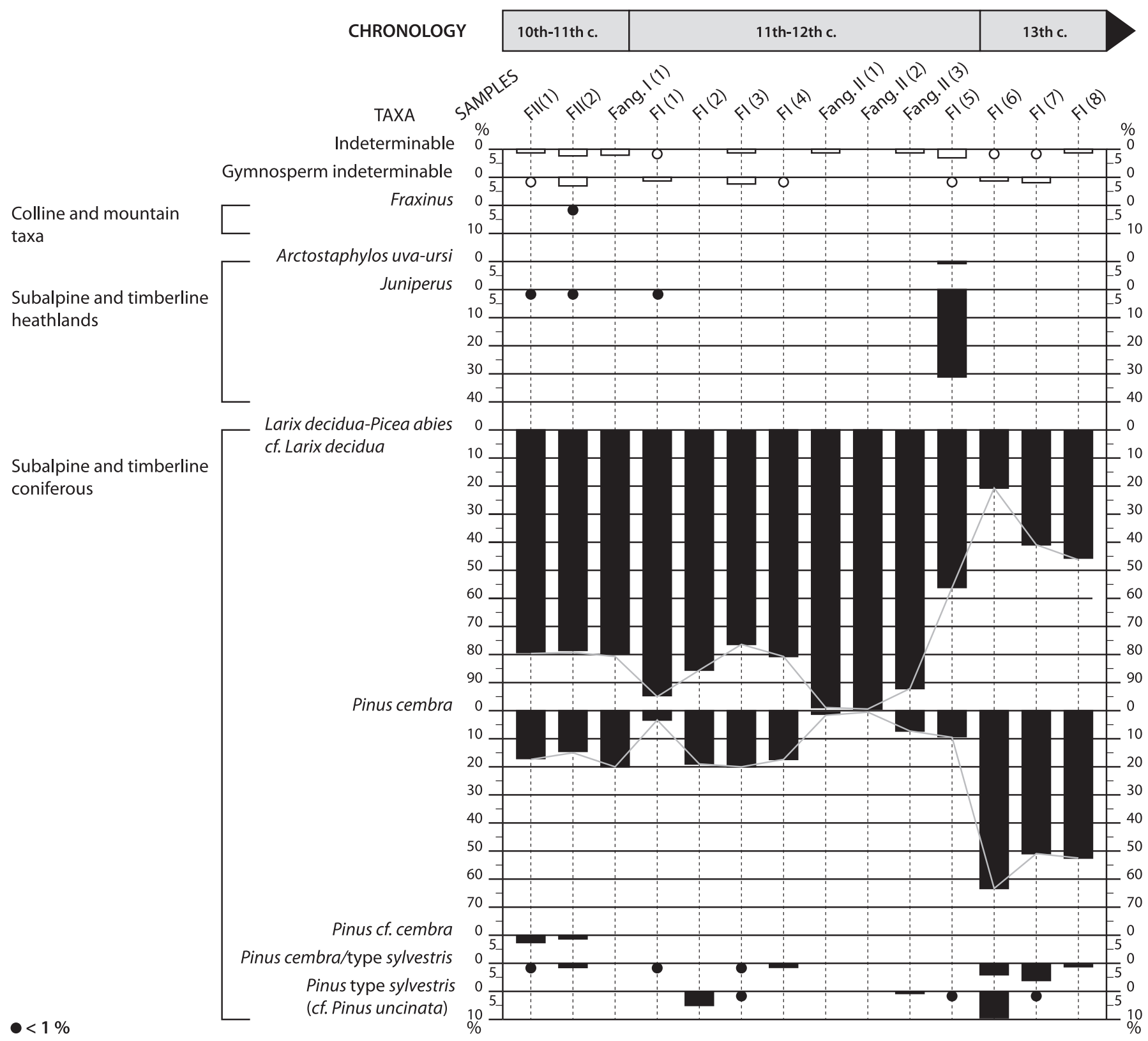

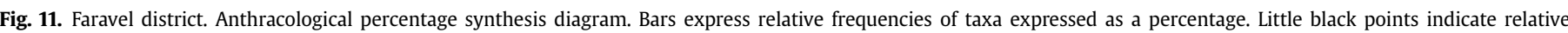
frequency $\leq 0.5 \%$. The spectra that are ordered according to the chrono-stratigraphy are organized in the anthracological synthesis diagram. 
Contemporary periods (mostly 19th c.). Here the Medieval and Antique imprints plot together, indicating similar contamination from the Argentière and Faravel ore districts. We may therefore conclude that the foreign $\mathrm{Pb}$ signature during the antique period is also associated with local ore extraction and processing. It should be noted that the "crustal cluster" seen in Fig. 9 is divided into two post- and pre- 1800 cal B.C. clusters in Fig. 10. The 1800 to 35356 cal B.C. is closer to the Faravel source imprint and may suggest early lead or copper mining in the Fangeas sector. An outlier measured in the Fangeas peat during the 19th c. explicitly characterises the Argentière mining district in Fig. 10, corroborating the intense mining activity during this period (Ancel, 2010, 2012).

\subsection{Fuel wood and timber for mining}

\subsubsection{Anthracological data}

Anthracological data concern fuel wood used for firesetting from the 10th c. A.D. up to the end of the 13th c. A.D. Faravel district's anthracological results were recently published in the form of an anthracological diagram (Py et al., 2013). Only 8 taxa were identified out of a total of 4015 fragments sampled from scattered charcoal deposits (Table 4 and Fig. 11). The taxa identified are: Arctostaphylos uva-ursi; Fraxinus angustifolia/oxyphylla/excelsior/ ornus (in table and diagram: Fraxinus); Juniperus; L. decidua/P. abies; P. cembra; Pinus cf. cembra; P. cembra/type sylvestris and Pinus type sylvestris (i.e. P. sylvestris L. and/or P. uncinata Mill. and/or P. nigra Arn. and/or P. mugo Turra). The taxa P. cembra/type sylvestris and Pinus cf. cembra do not refer to a botanical type but to an anatomical uncertainty (see Py et al., 2013). High mountain conifers largely dominate charcoal spectra in consistency with the altitudinal location of mines. Deciduous trees are marginal including mountain Ericaceae. From the beginning of the 10th c. up to the middle of the 12th c., larch/spruce taxon (probably L. decidua: see Py et al., 2013 and above $\S$ 4.1.2) has relative frequencies between 76.6 and $100 \%$. It is associated with arolla pine, with frequencies fluctuating between $1 \%$ and $20.1 \%$, and with Scots pine type in a minor way (probably P. uncinata: see Ali et al., 2003 and Py et al., 2013). A peak of juniper occurs during the 12 th c. It reaches $31.6 \%$ while it is minor in all other charcoal samples (Table 4). An inversion of the dominant taxon occurs during the middle of the 13th c.: larch becomes secondary (20.6-46.5\%) while arolla pine is dominant with 51.1$63.9 \%$. These two taxa are associated with Scots pine type that is better represented than in previous sequences.

Anthracological data from the Argentière district have been partially published (Py, 2006; Ancel et al., 2010). In this paper, results are presented in a data table and an anthracological diagram (Table 5 and Fig. 12). 22 taxa were identified for a total of 6731 fragments analysed from scattered deposits: A. alba; Acer; Alnus; Alnus/Betula; Betula; Clematis; Fabaceae; Fagus sylvatica; Fraxinus; Juglans regia; Juniperus; L. decidua-P. abies; P. cembra; Pinus type sylvestris; Populus; Quercus deciduous; Rosa; Rosaceae, Maloideae; Salix; Salix/Populus; S. aucuparia; Ulmus. Anthracological spectra are nearly all largely dominated by larch/spruce, whose frequencies mostly oscillate from 70 to $99 \%$. This subalpine taxon is associated with a Scots pine type whose frequencies oscillate from 0.5 to $5 \%$ and 10 to $37 \%$. In that case, according to palaeo- and biogeographical data, this Scots pine type is more likely $P$. sylvestris, a mountain species, rather than $P$. uncinata, a high altitude species (without excluding its presence). Along the sequence, its occurrence does not increase or decrease regularly but it is variable and irregular. A Scots pine type becomes dominant in only one sample from the second half of the 13th c. It is always associated with larch (23\%). Overall, its frequencies noticeably increase from the end of the 12th c. up to the end of the 13th c. while larch decreases (Fig. 12). Fir is the third taxon the best represented. Its frequencies

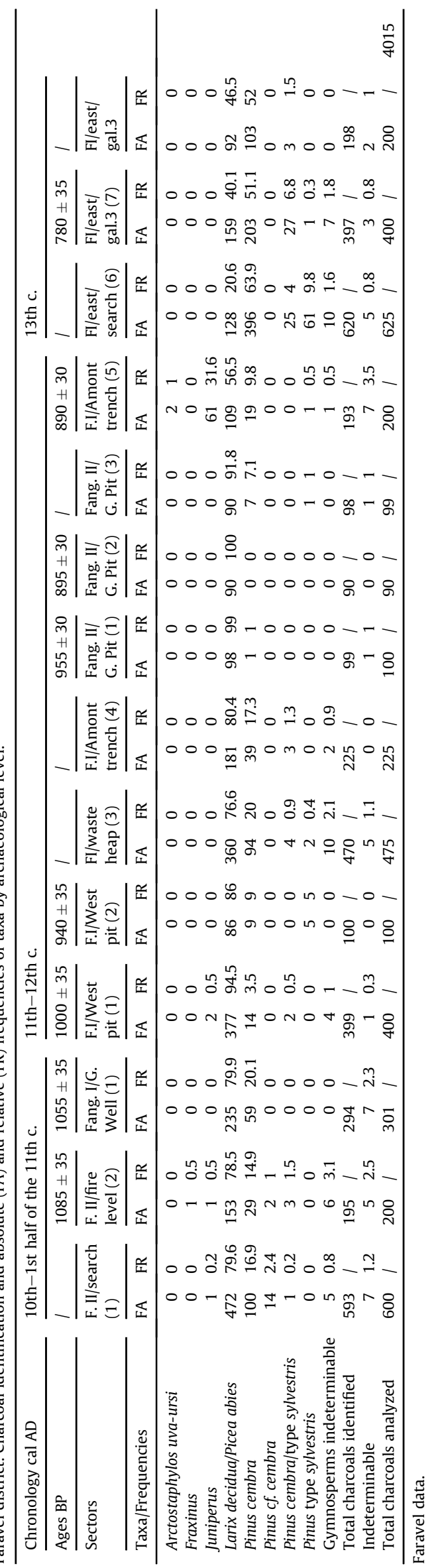


Table 5

Argentière district. Charcoal identification and absolute and relative frequencies of taxa by archaeological level.

\begin{tabular}{|c|c|c|c|c|c|c|c|c|c|c|c|c|c|c|c|c|c|c|c|c|c|c|c|c|c|c|c|c|c|c|c|c|c|c|}
\hline \multirow{4}{*}{$\begin{array}{l}\text { Chronology cal AD } \\
\text { Ages BP } \\
\text { Mining sectors/n }{ }^{\circ} \text { Samples } \\
\text { Taxa/Frequencies }\end{array}$} & \multicolumn{16}{|c|}{ 10th-1st half 11th c. } & \multicolumn{17}{|c|}{ 2nd half 11 th -1 st half 12 th c. } & \\
\hline & \multirow{2}{*}{\multicolumn{2}{|c|}{$\frac{1}{\text { Lauz./1 }}$}} & $1080=$ & \pm 40 & 1 & & 1 & & 1 & & 1 & & 1 & & $975 \pm$ & \pm 40 & 1 & 1 & & $915 \pm$ & $=35$ & 1 & & 1 & & $945 \pm$ & \pm 35 & 1 & & 1 & & & \pm 30 & \\
\hline & & & Lauz.| & .2 & $\mathrm{VT} / 1$ & & $\mathrm{SR} / 1$ & & $\mathrm{SR} / 2$ & & $\mathrm{SR} / 3$ & & $\mathrm{SR} / 4$ & & $\mathrm{SR} / 5$ & & $\mathrm{SR} / 6$ & $\mathrm{CB} / 1$ & & $\mathrm{CB} / 2$ & & $\mathrm{CB} / 3$ & & $\mathrm{SR} / 7$ & & $\mathrm{Pi} / 1$ & & $\mathrm{Pi} / 2$ & & $\mathrm{Pi} / 3$ & & $\mathrm{Pi} / 4$ & & \\
\hline & FA & FR $\mathrm{F}$ & FA & FR & FA & FR & FA & $\mathrm{FR}$ & FA & FR & FA & FR & FA & FR $\mathrm{F}$ & FA F & FR & FA $\quad F R$ & $\mathrm{FA}$ & FR & FA F & FR & FA & $\mathrm{FR}$ & $\mathrm{FA}$ & FR & FA & $\mathrm{FR}$ & FA & FR & FA & FR & FA & FR & \\
\hline Abies alba & 0 & 0 & 1 & 0.68 & 1 & 0.3 & 1 & 0.21 & 0 & 0 & 0 & 0 & 0 & 0 & 00 & 0 & 33 & 0 & 0 & 00 & 0 & 0 & 0 & 0 & 0 & 0 & 0 & 0 & 0 & 0 & 0 & & 0 & \\
\hline Acer & 0 & 0 & 1 & 0.68 & 0 & 0 & 0 & 0 & 0 & 0 & 0 & 0 & 0 & 0 & 00 & 0 & $\begin{array}{ll}0 & 0\end{array}$ & 0 & 0 & 00 & 0 & 0 & 0 & 0 & 0 & 0 & 0 & 0 & 0 & 0 & 0 & & 0 & \\
\hline Alnus & 0 & 0 & 0 & 0 & 0 & 0 & 1 & 0.21 & 0 & 0 & 0 & 0 & 0 & 0 & $0 \quad 0$ & 0 & $\begin{array}{ll}0 & 0\end{array}$ & 0 & 0 & 00 & 0 & 0 & 0 & 0 & 0 & 2 & 0.4 & 0 & 0 & 0 & 0 & 5 & 1.2 & \\
\hline Alnus/Betula & 0 & 0 & 0 & 0 & 0 & 0 & 0 & 0 & 0 & 0 & 0 & 0 & 0 & 0 & 00 & 0 & $\begin{array}{ll}0 & 0\end{array}$ & 0 & 0 & 00 & 0 & 0 & 0 & 0 & 0 & 1 & 0.2 & 0 & 0 & 1 & 0.4 & 0 & 0 & \\
\hline Betula & 0 & 0 & 0 & 0 & 0 & 0 & 0 & 0 & 0 & 0 & 0 & 0 & 0 & 0 & 00 & 0 & $\begin{array}{ll}0 & 0\end{array}$ & 0 & 0 & 00 & 0 & 0 & 0 & 0 & 0 & 2 & 0.4 & 0 & 0 & 5 & 2 & 0 & 0 & \\
\hline Clematis & 0 & 0 & 0 & 0 & 0 & 0 & 0 & 0 & 0 & 0 & 0 & 0 & 0 & 0 & $0 \quad 0$ & 0 & $\begin{array}{ll}0 & 0\end{array}$ & 0 & 0 & 00 & 0 & 0 & 0 & 0 & 0 & 0 & 0 & 0 & 0 & 0 & 0 & 1 & 0.2 & \\
\hline Fabaceae & 0 & 0 & 0 & 0 & 0 & 0 & 0 & 0 & 0 & 0 & 0 & 0 & 0 & 0 & 00 & 0 & $\begin{array}{ll}0 & 0\end{array}$ & 1 & 0.7 & 00 & 0 & 0 & 0 & 0 & 0 & 0 & 0 & 0 & 0 & 0 & 0 & 0 & 0 & \\
\hline Fagus sylvatica & 0 & 0 & 0 & 0 & 0 & 0 & 0 & 0 & 0 & 0 & 4 & 2 & 0 & 0 & $0 \quad 0$ & 0 & $0 \quad 0$ & 0 & 0 & 00 & 0 & 0 & 0 & 0 & 0 & 0 & 0 & 0 & 0 & 0 & 0 & 0 & 0 & \\
\hline Fraxinus & 0 & 0 & 1 & 0.68 & 0 & 0 & 0 & 0 & 0 & 0 & 0 & 0 & 0 & 0 & 00 & 0 & $\begin{array}{ll}0 & 0\end{array}$ & 0 & 0 & 00 & 0 & 0 & 0 & 0 & 0 & 0 & 0 & 0 & 0 & 0 & 0 & 0 & 0 & \\
\hline Juglans regia & 0 & 0 & 0 & 0 & 0 & 0 & 0 & 0 & 0 & 0 & 0 & 0 & 0 & 0 & 00 & 0 & $\begin{array}{ll}0 & 0\end{array}$ & 0 & 0 & 10 & 0.3 & 0 & 0 & 0 & 0 & 0 & 0 & 0 & 0 & 0 & 0 & 0 & 0 & \\
\hline Juniperus & 0 & 0 & 0 & 0 & 0 & 0 & 0 & 0 & 0 & 0 & 0 & 0 & 0 & 0 & 00 & 0 & $\begin{array}{ll}0 & 0\end{array}$ & 0 & 0 & 00 & 0 & 0 & 0 & 0 & 0 & 0 & 0 & 0 & 0 & 2 & 0.8 & 0 & 0 & \\
\hline Larix decidua-Picea abies & 98 & 98 & 87 & 59.2 & 333 & 98.5 & 447 & 94.1 & 127 & 84.7 & 193 & 95.5 & 377 & 747 & 739 & 97.3 & $91 \quad 91$ & 143 & 95.3 & $370 \mathrm{~s}-\mathrm{a}-\mathrm{a}$ & 98.7 & 97 & 78.2 & 153 & 76.5 & 410 & 88.9 & 375 & 98.7 & 193 & 77.5 & 328 & 78.8 & \\
\hline Pinus cembra & 0 & 0 & 0 & 0 & 0 & 0 & 0 & 0 & 0 & 0 & 0 & 0 & 0 & 0 & 00 & 0 & 00 & 0 & 0 & 00 & 0 & 0 & 0 & 0 & 0 & 2 & 0.4 & 0 & 0 & 0 & 0 & 0 & 0 & \\
\hline Pinus type sylvestris & 2 & 2 & 54 & 36.7 & 4 & 1.18 & 19 & 4 & 18 & 12 & 4 & 2 & 122 & 24 & 00 & 0 & 55 & 5 & 3.3 & 20 & 0.5 & 22 & 17.7 & 46 & 23 & 33 & 7.2 & 0 & 0 & 33 & 13.3 & 62 & 14.9 & \\
\hline Populus & 0 & 0 & 0 & 0 & 0 & 0 & 0 & 0 & 0 & 0 & 0 & 0 & 0 & 0 & 00 & 0 & $\begin{array}{ll}0 & 0\end{array}$ & 0 & 0 & 00 & 0 & 0 & 0 & 0 & 0 & 0 & 0 & 0 & 0 & 1 & 0.4 & 0 & 0 & \\
\hline Quercus deciduous & 0 & 0 & 0 & 0 & 0 & 0 & 1 & 0.21 & 0 & 0 & 0 & 0 & 0 & 0 & 00 & 0 & $\begin{array}{ll}0 & 0\end{array}$ & 1 & 0.7 & 00 & 0 & 1 & 0.8 & 1 & 0.5 & 6 & 1.3 & 0 & 0 & 1 & 0.4 & 11 & 2.6 & \\
\hline Rosa & 0 & 0 & 0 & 0 & 0 & 0 & 0 & 0 & 0 & 0 & 0 & 0 & 0 & 0 & 00 & 0 & $\begin{array}{ll}0 & 0\end{array}$ & 0 & 0 & 00 & 0 & 0 & 0 & 0 & 0 & 0 & 0 & 0 & 0 & 0 & 0 & 1 & 0.2 & \\
\hline Rosaceae, Maloideae & 0 & 0 & 0 & 0 & 0 & 0 & 0 & 0 & 0 & 0 & 0 & 0 & 0 & 0 & 00 & 0 & $0 \quad 0$ & 0 & 0 & $0 \quad 0$ & 0 & 0 & 0 & 0 & 0 & 0 & 0 & 0 & 0 & 1 & 0.4 & 0 & 0 & \\
\hline Salix & 0 & 0 & 0 & 0 & 0 & 0 & 0 & 0 & 4 & 2.7 & 0 & 0 & 0 & 0 & 00 & 0 & $\begin{array}{ll}0 & 0\end{array}$ & 0 & 0 & 00 & 0 & 0 & 0 & 0 & 0 & 1 & 0.2 & 0 & 0 & 1 & 0.4 & 1 & 0.2 & \\
\hline Salix/Populus & 0 & 0 & 0 & 0 & 0 & 0 & 0 & 0 & 0 & 0 & 0 & 0 & 0 & 0 & 00 & 0 & $\begin{array}{ll}0 & 0\end{array}$ & 0 & 0 & 00 & 0 & 0 & 0 & 0 & 0 & 2 & 0.4 & 0 & 0 & 1 & 0.4 & 0 & 0 & \\
\hline Sorbus aucuparia & 0 & 0 & 0 & 0 & 0 & 0 & 0 & 0 & 0 & 0 & 0 & 0 & 0 & 0 & 00 & 0 & $0 \quad 0$ & 0 & 0 & 00 & 0 & 0 & 0 & 0 & 0 & 0 & 0 & 0 & 0 & 3 & 1.2 & 0 & 0 & \\
\hline Ulmus & 0 & 0 & 0 & 0 & 0 & 0 & 0 & 0 & 0 & 0 & 0 & 0 & 0 & 0 & 00 & 0 & 00 & 0 & 0 & 00 & 0 & 0 & 0 & 0 & 0 & 0 & 0 & 0 & 0 & 0 & 0 & 1 & 0.2 & \\
\hline Gymnosperms indeterminable & 0 & 0 & 3 & 2.04 & 0 & 0 & 6 & 1.26 & 1 & 0.7 & 1 & 0.5 & 12 & 2 & 22 & 2.7 & 11 & 0 & 0 & 20 & 0.5 & 4 & 3.2 & 0 & 0 & 2 & 0.4 & 5 & 1.3 & 7 & 2.8 & 5 & 1.2 & \\
\hline Angiosperms indeterminable & 0 & 0 & 0 & 0 & 0 & 0 & 0 & 0 & 0 & 0 & 0 & 0 & 0 & 0 & 00 & 0 & $0 \quad 0$ & 0 & 0 & 00 & 0 & 0 & 0 & 0 & 0 & 0 & 0 & 0 & 0 & 0 & 0 & 1 & 0.2 & \\
\hline Total charcoals identified & 100 & 11 & 147 & 1 & 3387 & 1 & 475 & 1 & 150 & 1 & 202 & 1 & $50 /$ & 17 & 751 & 1 & $100 /$ & 150 & 1 & 3751 & 1 & 124 & 1 & 200 & 1 & 461 & 1 & 380 & 1 & 249 & 1 & 416 & 1 & \\
\hline Indeterminable & 0 & 0 & 3 & 2 & 3 & 0.88 & 0 & 0 & 0 & 0 & 1 & 0.5 & 0 & 0 & 00 & 0 & $0 \quad 0$ & 0 & 0 & 00 & 0 & 1 & 0.8 & 0 & 0 & 3 & 0.6 & 0 & 0 & 3 & 1.2 & 0 & 0 & \\
\hline Total charcoals analyzed & 100 & 11 & 150 & 1 & 341 & 1 & 475 & 1 & 150 & 1 & 203 & 1 & 501 & 17 & $75 \quad 1$ & 1 & $100 /$ & 150 & 1 & 3751 & 1 & 125 & 1 & 200 & 1 & 464 & 1 & 380 & 1 & 252 & 1 & 416 & 1 & 4006 \\
\hline Chronology cal AD & & half & 12th- & -1 rst ha & alf 13th & h c. & & & & & & & & & nd ha & alf 13th & $\mathrm{hc}$. & & & & & & & & & & & & & & & & & \\
\hline Ages BP & 1 & & & I & & I & & & 1 & & & 1 & & & $35 \pm 2$ & 45 & $770 \pm 4$ & & 1 & & & 1 & & 1 & & 1 & te & & 1 & & 1 & & & \\
\hline Mining sectors/n $\mathrm{n}^{\circ}$ Samples & $\overline{\mathrm{CB} / 4}$ & & & SR/7 & & $\overline{\mathrm{SR} / \mathrm{S}}$ & $/ 8$ & & $\overline{\mathrm{SR} / 9}$ & & & $\mathrm{VT} / 2$ & & & $\mathrm{~B} / 5$ & & $\mathrm{SR} / 10$ & & $\overline{\mathrm{SR} / 11}$ & & & $\mathrm{SR} / 12$ & & $\mathrm{CB} / 6$ & & & $V \mathrm{~T} / 3$ & & $\mathrm{VT} / 4$ & & & $\mathrm{~T} / 5$ & & \\
\hline Taxa/Frequencies & FA & & $\mathrm{R}$ & $\mathrm{FA}$ & FR & FA & & FR & FA & $\overline{F R}$ & & $\mathrm{FA}$ & FR & $\mathrm{FA}$ & $A$ & $\overline{F R}$ & $\mathrm{FA}$ & FR & FA & FR & & FA & $\overline{F R}$ & $\mathrm{FA}$ & FR & & $A$ & $\overline{F R}$ & $\mathrm{FA}$ & FR & FA & & FR & \\
\hline Abies alba & 1 & 1 & 1 & 4 & 2.67 & & 0 & 0 & 0 & 0 & & 0 & 0 & & 0 & 0 & 24 & 3.3 & 1 & 0.29 & & 0 & 0 & 3 & 1.96 & & 14 & 7 & 0 & 0 & & 0 & 0 & \\
\hline Acer & 0 & 0 & D & 0 & 0 & & $0 \quad 0$ & 0 & 0 & 0 & & 0 & 0 & & 0 & 0 & 0 & 0 & 0 & 0 & & 0 & 0 & 0 & 0 & & 0 & 0 & 0 & 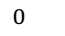 & & 0 & 0 & \\
\hline Alnus & 0 & 0 & b & 0 & 0 & & $0 \quad 0$ & 0 & 0 & 0 & & 0 & 0 & & 0 & 0 & 1 & 0.14 & 0 & 0 & & 0 & 0 & 0 & 0 & & 10 & 5 & 0 & 0 & & 0 & 0 & \\
\hline Alnus/Betula & 0 & 0 & D & 0 & 0 & & 0 & 0 & 0 & 0 & & 0 & 0 & & 0 & 0 & 0 & 0 & 0 & 0 & & 0 & 0 & 0 & 0 & & 0 & 0 & 0 & 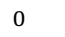 & & 0 & 0 & \\
\hline Betula & 0 & 0 & D & 0 & 0 & & $\begin{array}{ll}0 & 0\end{array}$ & 0 & 0 & 0 & & 0 & 0 & & 0 & 0 & 0 & 0 & 0 & 0 & & 0 & 0 & 0 & 0 & & 0 & 0 & 0 & 0 & & 0 & 0 & \\
\hline Clematis & 0 & 0 & D & 0 & 0 & & $0 \quad 0$ & 0 & 0 & 0 & & 0 & 0 & & 0 & 0 & 0 & 0 & 0 & 0 & & 0 & 0 & 0 & 0 & & 0 & 0 & 0 & 0 & & 0 & 0 & \\
\hline Fabaceae & 0 & 0 & D & 0 & 0 & & $\begin{array}{l}0 \quad 0 \\
\end{array}$ & 0 & 0 & 0 & & 0 & 0 & & 0 & 0 & 0 & 0 & 0 & 0 & & 0 & 0 & 0 & 0 & & 0 & 0 & 0 & . & & 0 & 0 & \\
\hline Fagus sylvatica & 0 & 0 & 0 & 0 & 0 & & $\begin{array}{l}0 \\
0\end{array}$ & 0 & 0 & 0 & & 0 & 0 & & 0 & 0 & 0 & 0 & 0 & 0 & & 0 & 0 & 0 & 0 & & 0 & 0 & 0 & 0 & & 0 & 0 & \\
\hline Fraxinus & 0 & 0 & 5 & 0 & 0 & & 0 & 0 & 0 & 0 & & 0 & 0 & & 0 & 0 & 1 & 0.14 & 0 & 0 & & 0 & 0 & 0 & 0 & & 0 & 0 & 0 & 0 & & 0 & 0 & \\
\hline Juglans regia & 0 & 0 & 0 & 0 & 0 & & 0 & 0 & 0 & 0 & & 0 & 0 & & 0 & 0 & 0 & 0 & 0 & 0 & & 0 & 0 & 0 & 0 & & 0 & 0 & 0 & 0 & & 0 & 0 & \\
\hline Juniperus & 0 & 0 & 0 & 0 & 0 & 0 & $\begin{array}{l}0 \quad 0 \\
0\end{array}$ & 0 & 0 & 0 & & 0 & 0 & & 0 & 0 & 1 & 0.14 & 0 & 0 & & 0 & 0 & 0 & 0 & & 0 & 0 & 0 & 0 & & 0 & 0 & \\
\hline Larix decidua-Picea abies & 86 & 58 & 36 & 142 & 94.7 & 153 & & 76.5 & 118 & 78.7 & & 91 & 72.8 & & 23 & 23 & 608 & 83.6 & 327 & 93.4 & & 84 & 84 & 114 & 74.5 & & 130 & 63 & 46 & 56.1 & & 14 & 77.8 & \\
\hline Pinus cembra & 0 & 0 & o & 0 & 0 & 0 & $0 \quad 0$ & 0 & 0 & 0 & & 0 & 0 & & 0 & 0 & 1 & 0.14 & 0 & 0 & & 0 & 0 & 0 & 0 & & 0 & 0 & 0 & 0 & & 0 & 0 & \\
\hline Pinus type sylvestris & 10 & & 10 & 4 & 2.67 & 46 & & 23 & 30 & 20 & & 30 & 24 & & 77 & 77 & 85 & 11.7 & 20 & 5.71 & & 14 & 14 & 33 & 21.6 & & 49 & 24 & 30 & 36.6 & & 59 & 21.5 & \\
\hline Populus & 0 & 0 & j & 0 & 0 & & $\begin{array}{l}0 \\
0\end{array}$ & 0 & 0 & 0 & & 0 & 0 & & 0 & 0 & 0 & 0 & 0 & 0 & & 0 & 0 & 0 & 0 & & 0 & 0 & 0 & 0 & & 0 & 0 & \\
\hline Quercus deciduous & 0 & 0 & & 0 & 0 & & 10. & 0.5 & 0 & 0 & & 0 & 0 & & 0 & 0 & 0 & 0 & 0 & 0 & & 0 & 0 & 0 & 0 & & 0 & 0 & 0 & 0 & & 0 & 0 & \\
\hline Rosa & 0 & 0 & b & 0 & 0 & & 0 & 0 & 0 & 0 & & 0 & 0 & & 0 & 0 & 0 & 0 & 0 & 0 & & 0 & 0 & 0 & 0 & & 0 & 0 & 0 & 0 & & 0 & 0 & \\
\hline Rosaceae, Maloideae & 0 & 0 & 0 & 0 & 0 & & 0 & 0 & 0 & 0 & & 0 & 0 & & 0 & 0 & 0 & 0 & 0 & 0 & & 0 & 0 & 0 & 0 & & 0 & 0 & 0 & 0 & & 0 & 0 & \\
\hline Salix & 0 & 0 & o & 0 & 0 & & 0 & 0 & 0 & 0 & & 2 & 1.6 & & 0 & 0 & 0 & 0 & 0 & 0 & & 0 & 0 & 0 & 0 & & 0 & 0 & 0 & 0 & & 0 & 0 & \\
\hline Salix/Populus & 0 & 0 & b & 0 & 0 & & 0 & 0 & 0 & 0 & & 0 & 0 & & 0 & 0 & 0 & 0 & 0 & 0 & & 0 & 0 & 0 & 0 & & 0 & 0 & 0 & 0 & & 0 & 0 & \\
\hline
\end{tabular}


are always less than $5 \%(0.2-3.3 \%)$ except in a spectrum dated to the second half of the 13th c. where they attain 7\%. Deciduous trees, very poorly represented, do not exceed $5 \%$ : even deciduous oak $(0.2-2.6 \%)$, which is still the most frequent one.

Table 6

Dendrochronological series distribution.

\begin{tabular}{lllllll}
\hline Species & $<50$ tree rings & $50-99$ & $100-149$ & $150-199$ & $>200$ & Total \\
\hline Larix decidua/ & 29 & 50 & 38 & 14 & 7 & 138 \\
$\quad$ Picea abies & & & & & & \\
Pinus cembra & 1 & 11 & 3 & 1 & 1 & 17 \\
Others & 1 & 0 & 1 & 0 & 0 & 2 \\
Total & 31 & 61 & 42 & 15 & 8 & 157 \\
\hline
\end{tabular}

In both districts, the few charcoals of deciduous trees are often tiny and badly conserved (their edges are rounded). Furthermore, these charcoals come from knots or wood tissues in contact with knots. The transversal plane's aspect does not necessarily fit descriptions from xylology atlases, frequently based on mature trees. Consequently, it was not possible to evaluate the growth ring curvature for most of these. In the best-preserved fragments, minimum initial diameter of wood is between 0.3 and $10 \mathrm{~cm}$. The diameters are mostly between 0.3 and $2 \mathrm{~cm}$. This kindling constitutes a very small proportion of the fuel wood used by the miners $(0.7 \%)$. All the other fragments have rectilinear growth rings. Therefore, they originate from trunks or branches with a diameter $>10 \mathrm{~cm}$. In various samples, the relative frequencies of charcoal fragments with compression wood are mostly between 0 to $10 \%$ and 10 to $20 \%$ and rarely exceed $40 \%$ (Fig. 13 ).

\subsubsection{Dendrological data}

The lengths of the growth ring sequences and the growth patterns provide information on the age of the trees used for timbering and mining equipment. Distribution of the lengths of the series provides a minimum age distribution (Table 6). The vast majority of trees used were aged between 50 and 150 years. The analysed timbers are often pieces of trunks with series of thin and almost rectilinear growth rings. Corresponding trees were probably mature or old. Timber of wide cross-sections used to square-cut poles and beams or to cut boards show long sequences of very thin tree rings. They provide ring sequences $>200$ years old, characteristic of mature or old trees. The props - between 5 and $23 \mathrm{~cm}$, but especially between 9 and $12 \mathrm{~cm}$ in diameter - are between 25 and 50 years old, corresponding to young trees. It is still not possible to quantify the age distribution of all trees used for firesetting and timbering. These data nevertheless indicate the presence of woodland in which trees differ markedly in age. Only seven dated wood specimens have conserved their pith, which indicates the start of the tree growth of a few years. Consequently several events of the larch regeneration were characterised: they range from the end of the 8th c. A.D. to the beginning of the 12th c. A.D. $(777-952-1043-1013-1147-1135$ - (before 1006) - 1085).

\section{Discussion}

The results of the study show important changes to vegetation and human activities during the Holocene that can be explained by interdisciplinary viewpoints on mining, forestry and agropastoral practices and their chronology. 


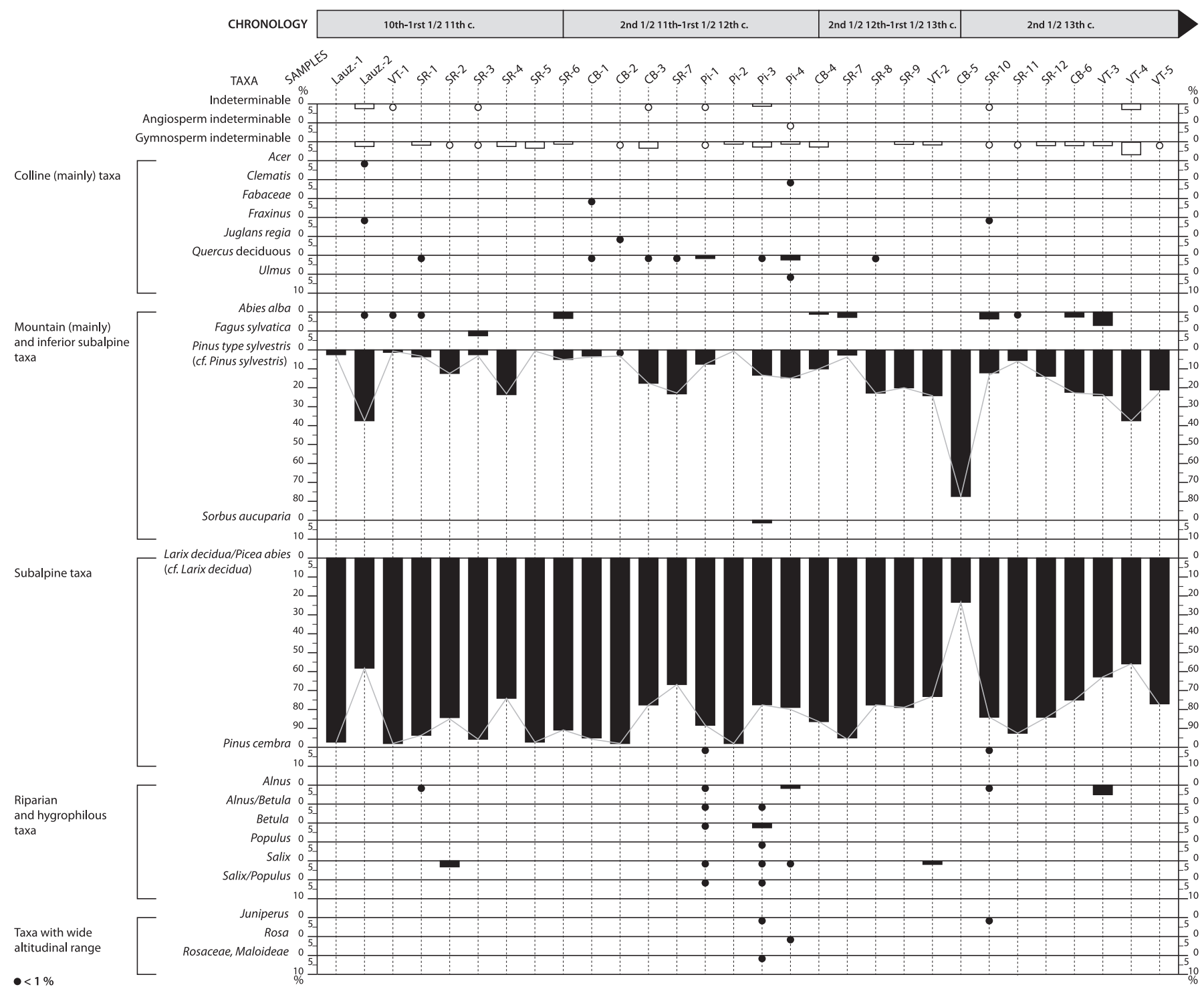

Fig. 12. Argentière district. Anthracological percentage synthesis diagram.

\subsection{Recent Prehistory and Bronze Age}

Pollen spectra of recent prehistory are characteristic of woodland dominated by pine (Fig. 7). They suggest the existence of a tall dense forest at potentially high altitudes (2200-2400 m asl). In parallel, nonarboreal pollen indicates forest openings. Pollen records reconstruct a wooded-meadow landscape dominated by arolla pine forest. The very low quantity of tree macro-remains found in the peat bog could reinforce this hypothesis because it may indicate the absence of woodland cover in the vicinity of the wetland. The contrary is known in adjacent mountains where abundant pine fossil trunks and macro-remains were conserved in several wetlands that were forested in the past and today above the timberline (i.e. Lake Canard in the Taillefer Massif: Ponel et al., 1992; and Lake Cristol above Briançon: Nakagawa et al., 2000). The continuous curve of silver birch also militates in favour of the presence of open areas. Its association with arolla pine is likely at the timberline. As a pioneer species, silver birch played a leading role in progression of the timberline during the Holocene (Fauquette, 1995; Edouard and Thomas, 2008). Pollen indicators of pastoralism are tenuous during the Neolithic and the Bronze Ages.
However, archaeological discoveries -Prehistoric seasonal hunting halts and Bronze Age pastoral structures- indicate human and pastoral presence in the upper Freissinières valley (see: Leveau and Segard, 2004a; Walsh et al., 2010, 2014). In the diagram (Fig. 7), this human presence can be understood by the change in the floral composition of mountain forests with the decline of silver birch, the development and progression of larch at altitudes of 2000$2200 \mathrm{~m}$ (Kharbouch, 2000). This phenomenon reached its first peak around the Early Bronze Age. Similar observations have been made for the Drac Noir upper valley (Court-Picon, 2003; Court-Picon et al., 2007). By and large, in the pollen diagrams of the Alps, the Bronze Age is characterised by forest clearing, grassland progression and the appearance of pastoral indicators (Beaulieu, 1977; Beaulieu et al., 1994; Bintz et al., 1999; Argant and Argant, 2000; Segard et al., 2003; Richer, 2009).

Calculated EFs and $\mathrm{Pb}$ isotopes highlight a possible mining activity between 1800 and 353-56 cal B.C. in the Fangeas area (Figs. 8 and 10), with possible lead-copper extraction from the Faravel district. Locally, archaeology has not yet detected mining works from this period. But when considering the regional mining context (see regional setting section), it is plausible that 


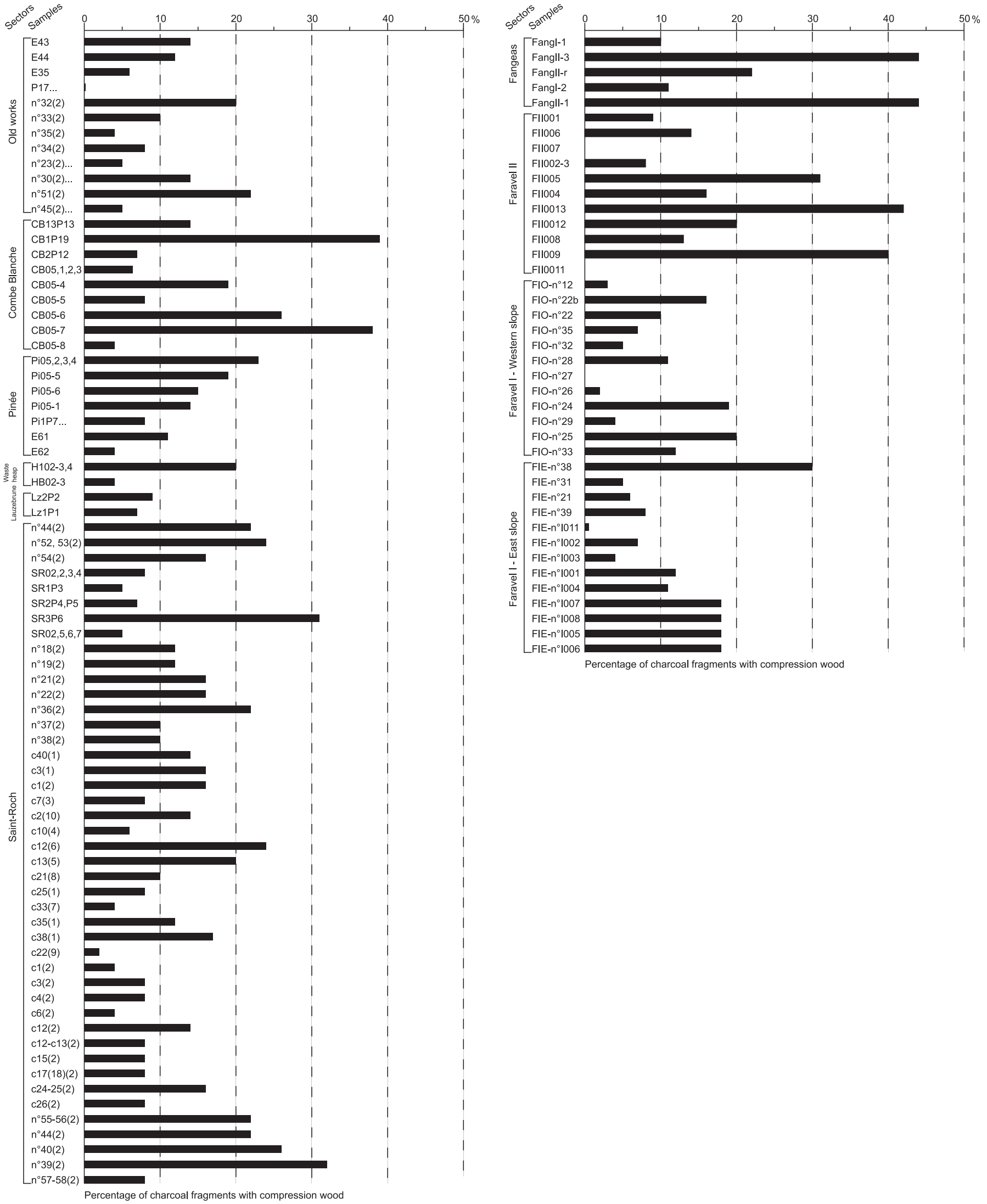

Fig. 13. Bar chart of charcoal frequencies with compression wood in the different samples (Argentière district on the left and Faravel district on the right). 
the Fangeas sector had already been prospected leading to the recognition of very small-sized ore deposits. The presence of minor works of unsuccessful research on chalcopyrite veinlets could testify to this activity, but these have not yet been dated (e.g. work faces less than $1 \mathrm{~m}$ depth and exploration trenches opened by firesetting). To this day, data remain extremely tenuous and the hypothesis of protohistoric mining prospecting activity in this area needs to be corroborated by archaeological field findings. Moreover, we cannot completely exclude regional contamination from the Massif des Rousses (strong north winds) and Saint-Veran (east winds). Thus, archaeological explorations of pastoral remains suggest that the changes to vegetation recorded by palynology are probably due to the development of seasonal altitudinal pastoral activity (transhumance) (Walsh et al., 2014). Mining archaeology and geochemistry show that this anthropisation process of the high mountain is also contemporary with mining exploration and activities at a local and/or regional scale (Bourgarit et al., 2008; Carozza et al., 2010).

The relatively low sedimentation records from the Early Bronze Age to the middle of the Iron Age is probably due to a complex combination of natural (climatic changes) and anthropogenic (peat exploitation?) factors that have not yet been successfully characterised (Walsh et al., 2006). In the future, this point could be clarified by sedimentological analyses of Fangeas peat sediments.

\subsection{Iron Age and Roman era}

The pollen diagram shows that vegetation changes become more noticeable towards the Late Iron Age (zone 2, see Fig. 7). The sharp decline in arboreal pollen, in connection with the rise in Poaceae and ruderal-steppe taxa, indicates a significant opening in woodland cover. Besides, high frequencies of pastoralism indicators, especially regular occurrence of $P$. lanceolata and Urticaceae associated with a peak of Rumex, suggest an intensification of pastoral activity at a local scale. However, discovered archaeological remains are rare and they fit in the continuity of traces from the former period (Segard et al., 2003; Leveau and Segard, 2004a, 2004b). In parallel, the spreading of larch, a species capable of colonising open areas or bare soil could be interpreted as an environmental response to the retreat of arolla pine, in turn signalling a lowering timberline. Additionally, the increase of fir, beech and oak and the reduction of pine indicate the stronger manifestation of extra-regional pollen and thus gaps in the subalpine forest cover. These transformations precede a phase of woodland encroachment in mid- to high-altitude areas and lessening of local pastoral activities between the end of the Iron Age and the second to third centuries A.D. In parallel, the grasslands pollen peak could be explained by their extension in altitude consequent to a combination of poorly identified anthropogenic and climatic factors (warming). Alpine and subalpine herbaceous grassland plants bloom in summer during the mountain pasture. Grazing temporarily removes the aerial parts of plants but does not destroy them, since they stock their energy in their roots and regenerate during the winter. However, regular intensification and occurrence of mountain pastoralism can potentially damage pollen production. The end of the Roman era is marked by a new retreat in arboreal pollen in subalpine levels and below. This retreat is characterised by the intensification of forest resource consumption and/or clearings from the foothills to the highlands. Clearing also results in a predominance of Poaceae and preservation of ruderal-steppe taxa and Cyperaceae.

It is between 353 and 56 cal B.C. and 128-323 cal A.D. that the $\mathrm{Pb}$ isotopic signatures vary significantly suggesting Roman mining activity in the two mining districts (Figs. 8, 9 and 11). Roman activity can be situated at the turn of the Era using date interpolation. This suggests continuity between the pre-Roman and Roman mining and it is the first evidence of local mining and/or metallurgical activity for this period. However, to this day, this activity has not yet been archaeologically verified. In the Argentière district, all explored ancient mining works, i.e. opened by firesetting, are medieval (cf. infra). But, the remains of a superficial Roman exploitation could have been destroyed by the various phases of the reactivation of mining activities. In the Faravel district, the inventoried mines, including minor exploration works on chalcopyrite and lead veinlets, have not yet all been dated. Geochemistry thus invites us to develop fieldwork (surveys and prospecting). Currently, a new research program concerning these mining explorations is in preparation.

Archaeological field evidence for Roman mining in the French western Alps is limited (Arnaud et al., 2005; Ancel, 2010), mostly concerning sites dedicated to iron metallurgy (Morin and Rosenthal, 2006) and more rarely polymetallic deposits. It is thus premature to establish a link between the fragmentation of the mountain forest (fir, oak, pine) and pre-Roman or Roman mining activities. On the one hand, the development of cultivated land in foothills and agrosylvopastoral practices at medium altitudes (midseason pastures, temporary cultures) could explain this deforestation. On the other hand, an intensification of forest harvesting for the production of lumber and fuel for other varied activities (e.g. building and energy production) could be the reason. In the neighbouring Champsaur, the Roman epoch is also characterised by an intensification of anthropogenic pressure on the fir forest. This latter favoured the expansion of beech adapted to forest grazing and thus the expansion of sylvopastoral practices, such as woodedmeadow (Court-Picon, 2003). In the upper Durance valley, like in the rest of the western Alps, limited archaeological exploration of these mid-altitudes $(1200-1600 \mathrm{~m})$ has taken place because nowadays, these altitudes are forested and field surveys are difficult to carry out.

\subsection{Late Antiquity and Early Middle Ages}

Geochemistry and mining archaeology enable this chronological sequence to be situated between -21 and $-20 \mathrm{~cm}$ and -16 and $-15 \mathrm{~cm}$ (Figs. 7 and 8). This level records an abatement of human pressure on the mountain, although with continuity of herd presence. Whether in mid- or high-altitude mountain areas, the forest regenerates where this abandonment is the most evident. Incidentally, thickets and alder bushland develop (wetland areas left fallow?). This scenario is comparable to the one described in the Champsaur based on pollen analysis of the Faudon lake (CourtPicon, 2003). However, it cannot be generalised for the entire South Alpine massif, as other sectors during this same period saw sustained -even intensified- human pressure (Court-Picon, 2003). In the Fangeas pollen diagram, towards the middle of this sequence $(-18 \mathrm{~cm})$, regression of the pine curve together with a new rise in both the grassland curve and the second cereal pollen curve could signal an increase in human activity. However, this phenomenon is barely documented by archaeology. So far, only one pastoral site, dated to the Carolingian era, has been discovered on the Fangeas plateau at $2000 \mathrm{~m}$; one occupation from late Antiquity has been characterised in the Champsaur (Palet-Martinez et al., 2003). One rare preserved written source of the Carolingian era -the Abbon testament- mentions a shepherd in the Vallouise (neighbouring valley), named Marius, responsible for leading his master's flock to the mountain pastures (Geary, 1985, p. 52, 20). In the main, the reduction in oak and pine frequency in the upper Durance could signify stability of, or even an increase in, human pressure in the foothills and in the valley, with mountain pastoralism phasing out. 
The sequence preceding the significant second variation of ${ }^{206} \mathrm{~Pb} /{ }^{207} \mathrm{~Pb}$ ratios and the sharp increase of the crustal enrichment factor is associated with another major clearance phase (Figs. 7 and 8 ) that may arise from mining activities, as suggested by archaeological findings. Mine prospecting dating from the end of the Carolingian era is clearly associated with land clearing by burning at approx. $2000 \mathrm{~m}$ altitude (Py et al., 2013). Anthracological analysis of a fire level reveals a forest landscape dominated by larch associated with arolla pine, in a secondary position (Fig. 11). Because Faravel's mining works dating from the 10th c. were extremely modest and were unsuccessful, they could not be documented by dendrochronology records. The establishment of new agropastoral subalpine areas results in, or is simultaneous with, scraping of some mineral-bearing outcrops. At Argentière, the first superficial mining works could be linked to this period (Fig. 5). In both districts, local tree species were used for firesetting. Larch was prioritised whereas pine was secondary. Fir and deciduous trees were marginal. In the pollen diagram, the retreat of pine, oak and fir thus cannot be due to mining only, at least not to ore extraction (firesetting). However, from this level $(-16-15$, see Fig. 7$)$, the pollen indicators show a sudden return to agropastoral activities at midto high-altitudes. The severe reduction in grassland pollen confirms this hypothesis. Towards the end of the Early Middle Ages, the development of pastoralism and the formation of new mountainous agropastoral areas in a larch-dominated landscape can be observed. The latter's frequency is lessened in these South-Alpine pollen diagrams due to its low capacity for pollen dispersal (Beaulieu, 1977; Kharbouch, 2000). Pastoral archaeological evidence supporting palaeoenvironmental data is lacking for the upper Durance valley, but does exist for the Champsaur (PaletMartinez et al., 2003).

\subsection{High and Late Middle Ages}

Archaeological and geochemical data enable the High and Late Middle Ages to be situated between -15 and $-10 \mathrm{~cm}$ (Figs. 7 and 8). Specific isotopic imprints from Argentière and Faravel are likely to be recorded during the Middle Ages in the Fangeas core. The sharp increase of the crustal enrichment factor corroborates this activity during the High Middle Ages. A manuscript dating from 1250 A.D. (Probus) attests to the existence of a smelting and refining workshop at Argentière (Py, 2009, I, 164-170). The pollen diagram characterises strong human pressure from the foothills to the highlands and the peak of forest clearance. The explosion of Poaceae $(70 \%)$ marks the maximum development of meadows at midto high-altitudes. Pine are at their lowest whereas the larch remains constant and even manages to colonise less impacted areas or those earmarked as wooded-meadows. Nonarboreal pollen frequencies (plantain, Renonculaceae, Cyperaceae, ruderal-steppe taxa) are the signature of regular pastoralism, maintenance of grazing areas and fodder production. These dramatic changes to the vegetation, determined by drastic deforestation and the explosion of pastoral markers have also been found in the Champsaur for the same period (Lauzons and Faudon lakes). They have been attributed to an increase in local and transhumance herds, but also to the success of fodder-producing and pastoral farming systems founded on the use of fire (Court-Picon, 2003; Durand, 2004, I, p. 151 and following). This practice could be responsible for the extinction of less fireresistant ligneous species such as fir and beech found on northfacing slopes. In the upper Durance, lead ore mining forms part of this successful agropastoral mountain economy context.

In the Faravel district, dendrochronological and radiocarbon dates suggest a cyclical, non-regular mining activity (Figs. 5 and 6). The minor deposits were mined in a discontinuous fashion for over three centuries, thus mining pressure on forestry resources was moderate. The distribution of dendrochronological dates suggests however a continuum of activity from 1182 to 1223 A.D., equalling a period of 42 years. At a regional scale, this period is also well represented in the dendrochronological sequences of mountain pastures' chalets-barns in several hamlets and villages (Edouard, 2010a, 2010b).

Anthracology characterises a local, subalpine and supra-forest zone timbershed (Py et al., 2013). For firesetting, the miners chose the biggest, most widespread conifers. The exploited woodland is first dominated by larch, followed by arolla pine associated with larch (Fig. 11). Larch is also the priority timber for shoring works and mine equipment. The dendrological approach characterises trees of varying ages. The age classes of trees reflect a forest that regenerates itself. Witnesses remain in the form of ancient isolated patches of vegetation in the valley and in the high surrounding valleys (e.g. under the Tête de Vautisse, larches over 500 years old grow) (Edouard and Thomas, 2008; Edouard et al., 2010). Over the course of several centuries, an expansion of the timbershed, towards these timberline patches of vegetation, is the most plausible hypothesis (Py et al., 2013). This strategy results in a decline in subalpine forest areas that were dominated by larch during the High Middle Ages. In parallel, supra-forest areas reveal their maximal expansion.

At Argentière, the mines are of industrial size for this period. The magnitude of works presumes continuous exploitation during the High Middle Ages confirmed by radiocarbon dating. The anthracological spectra are nearly exclusively dominated by larch associated with the secondary (or marginal) pine, of Scots type (Fig. 12). These spectres characterise a thinned high forest. The frequency of these two taxa fluctuates in a cyclical manner. The timbershed principally covers the north-facing slope of the subalpine woodland massif, which is clearly denser. It is regularly reoriented to the impoverished south-facing subalpine sites and/or to the intermediary south-facing and north-facing slopes (upper mountain and timberline levels). The exploited forested areas are compressed and fragmented by the mid-seasonal pastures and temporary crops and grasslands. With a clearing paroxysm found in written sources (Falque-Vert, 1997, 2004; Durand, 2004, I, p. 83 onwards), such as in pollen diagrams of the Southern Alps, their expansion was without doubt significant during the 12 th-13th centuries. This state of affairs involves both a timetable to be drawn up as well as an organised displacement of the mining timbershed, based on the rhythm of forest regeneration. Besides, it is plausible that the timbershed stretched out to woodland areas situated at great distances from the mines, towards valley extremities and in the uplands. As did the farmers, the miners also clearly preferred the progression of larch, more productive than pine. However, the increase in agropastoral zones progressively led to the drastic reduction of larch. Over the course of the 13th c., the sensitive yet significant increase of pine in the pollen diagram might be a reminder of the larch yield depletion. At Argentière, this reduction is supported by a clear timbershed decrease in mountainous fallow areas colonised by Scots pine. Sound communal management of woodland areas for mining and agropastoral activities is not recognized by palynology. It is thus primordial to associate palynological and archaeobotanical approaches in order to provide information on recent anthropogenic events, in particular for mining. From the High Middle Ages, the lords encouraged argentiferous resource mining, particularly since free access had been granted to forestry resources, managed by the communities of inhabitants and craftsmen. In actual fact, the mastery of the production of this metal was political and strategic (Bailly-Maître, 2002). Multidisciplinary works carried out in the Mont-Lozère offer converging results (Allée et al., 2010). Furthermore, this period of prosperity of the medieval alpine society corresponds to a considerable peak in lead 
contamination that has had an impact on the health status of these mountain communities.

\subsection{Modern and Contemporary periods}

Geochemical data enable the 19th c. to be situated around a depth of $-7.5 \mathrm{~cm}$ (Figs. 7 and 8). It suggests that the Modern period and the Industrial Revolution are localised between -10 and approx. $-7.5 \mathrm{~cm}$. On this sedimentary sequence, environment pressure continues, but in a different manner. Although pine increases significantly, larch, arolla pine, oak, fir and beech curves are all at their lowest. They perhaps express the intensive sampling carried out by the French Royal Navy (timber) and the fortress troops of Embrun, Briançon and Mont-Dauphin (timber and fuel) in the 17th and 18th centuries. They particularly affected the Freissinières and Argentière communities and the neighbouring communities of Guillestre, Vars, Réotier, Champcella and La Roche-deRame (Guillaume, 1887). The "Réformation générale des bois de la Province du Dauphiné" with the Hautes-Alpes forest state in 1727 and following years provide information on the state and the composition of forests. The finest woodland areas develop on the north-facing slopes above hamlets and crops. They are composed of pine and larch. Pine is situated on the lower slopes and larch on the upper ones. Fir coexists with larch in the valley bottom where it is relatively cool. Pine colonises the driest slopes and forms an important part, but not the majority, of communal forests of the upper Durance. They are over-represented in the pollen diagram whereas firs, but mainly larch, are under-represented. This interpretation is also valid for the 19th c., period for which valuable statistical data is available for each species (Billecard, 1890). Pastoralism indicators, especially plantain, mark a major development in herd and transhumance intensification, as found in written sources (Buffault, 1910). Grassland deterioration is characterised by Poaceae retreat. In the last seven centimetres, the sharp new increase of the pine curve is probably due to the afforestation programme of the uplands (RTM), which commenced during the last decades of the 19th c. The chosen species were principally Austrian and Scots pines. They were reputed for their capacity to maintain and stabilise eroded soil on sloping ground, in particular for southfacing slopes (Chauvin and Vallauri, 2002). The same applies for alder that was considered of great interest by reforestation agents. The extraction of alder plants forming strong roots was strongly advised for reforesting eroded slopes. The cultivation of coppiced alder stands at mid- and high-altitudes during the 19th c. resulted in an increase in their curve at the end of the sequence. Locally, agricultural decline is visible mainly at the end of the sequence $(-2 \mathrm{~cm})$ with the retreat of nonarboreal taxa and cereals. In accordance with local history, local agropastoral activity continues up to the second half of the 20th c. In 1960, the cables that were used to descend the hay from the mountain pasture down to the valley were still in use. On a regional scale, the agricultural decline is visible from $-7 \mathrm{~cm}$ (Fig. 7) with the sudden increase in arboreal taxa.

In parallel, geochemical data from Fangeas peat sediments suggest (i) a shift towards modern imprints that are clearly different from the medieval $\mathrm{Pb}$ contamination signatures and (ii) the imprint of the Argentière $\mathrm{Pb}$ ore mining district during the 19th c. Firstly, the modern imprints can be attributed to various attempts to exploit the Argentière mining district during the 17th and the 18th centuries. Manuscripts report two attempts in the Argentière district in 1670 and 1740 A.D. that were not characterised by archaeology because they were probably narrow and ineffective (Ancel, 2006). An important attempt took place between 1788 and 1793 with the construction of a factory with an ore washery and a cupellation smelter that functioned for only one campaign before the Revolution broke out. Besides, in this area, two other ore deposits were subject to an exploitation attempt: the copper deposits in the Faravel district (1772 A.D.) and the neighbouring silver-lead deposits of La Salcette (1781 A.D.) (Prelles, Saint-Martin de Queyrières) (Ancel, 2006). These mining works have left an embellished trace in local memory and in written sources, but they were unsuccessful and ephemeral adventures. However, their traces were clearly recorded in the Fangeas peat bog. Secondly, considerable mining development took place at Argentière during the mid-19th c. Mineralurgy was undertaken in situ in the technologically innovative workshops of the time, whereas lead metallurgy developed away from the Alps, first in Vienne (Isère), and then in Marseille. The particular mining conditions in Argentière (very hard wall rock, generalisation of backfilling) explain the limited use of timber (there is no mention of woodland conflict in the archives; Ancel, 2008, 2012). Mining activity definitively came to a halt at the beginning of the 20th c. Historical data supports geochemical findings from the top of the Fangeas sequence that show isotopic shifts toward recent regional industrial/petrol imprints and a sharp decrease of the EFs owing to the halt of local mining and metallurgical activities.

\section{Conclusions}

The results of this study show that it is crucial to combine archaeological, historical archaeobotanical and palaeoenvironmental approaches in order to achieve a detailed reconstruction of industrial and paleoecological history of a mining territory. The upper Durance valley is characterised by a complex overlay of different activities within a single alpine area. Such a multidisciplinary approach allows the differentiation of the environmental impact from mining and agropastoralism in the Fangeas pollen diagram. Pollen and geochemical anthropogenic markers complement field archaeology findings. $\mathrm{Pb}$ isotopes and trace metal enrichments in Fangeas peat core suggest mining activities during the protohistoric and Roman periods. None of these mining episodes were evident from field archaeological observations. The Faravel district probably contributes to the protohistoric isotope imprints recorded from Fangeas peat sediments but other sources of contamination are not excluded. Both mining districts contribute to the Antique episode. Through geochemistry, the archaeological survey will be oriented towards undated superficial remains that, to date have received no attention from archaeologists. This provisional protohistoric mining exploration would have coincided with landscape clearings subsequent to increased high-mountain agropastoral activities. By contrast, the Roman phase occurred when pastoral pressure was lessening in the uplands. At the end of the Carolingian era, mining activity resumed with agropastoral area expansion towards upper sections of small valleys in both Faravel and Argentière. In the Faravel district, dendrochronology reveals that mining activity was discontinuous. This activity lasted several centuries comprising several campaigns, each lasting from a couple of years to a couple of decades. Its impact on the forest was moderate. The dendrological study of timber characterises the exploitation of a mixed forest with trees of varied ages that regenerate in places. In the Argentière valley, where deposits are the most significant, mining activity was continuous during the High Middle Ages. Such activity favoured a rational, sustainable management of the subalpine woodland areas that were maintained to ensure mining yields and to fulfil farmers' needs. Mining contributed to favouring larch progression, an emblematic species of southern Alpine flora and culture. During the 13th c., the peak of agropastoral and mining activities led to a reduction in larch productivity, as witnessed by anthracology. Changes in wood supply strategies are noticeable from the anthracological diagrams. Woodland extraction 
also took place in intermediary, supra-forest and mountainous areas. Investigation of charcoal production sites would probably help understand better forest management as associated with mining activities. Ore-transformation workshops are also a source of woodland extraction that is poorly understood in our study area. The modern mining activity phase is equally highly discontinuous with reactivation attempts during the 17th and 18th centuries and one significant during the 19th c. Geochemical analyses have accurately distinguished these different episodes in the Fangeas core resulting it imprints from both mining districts to be distinguished. During the Modern and Contemporary periods, mining activity has been disconnected from the history of forests. Manuscripts and texts reveal the impact on vegetation consequent to the exploitation of timber for shipyards, farming, military practice and pastoralism. This pressure generated instability in mountainous regions threatened by erosion and torrential regimes. The impacts of natural hazards associated with deforestation have been limited owing to management by a significant afforestation programme whose positive effects have been clearly characterised by our study.

\section{Acknowledgements}

Funding for this research was raised from a CNRS ECLIPSE II project (Étude comparée des évènements climatiques et des activités anthropiques dans les Alpes méridionales: approche hauterésolution au cours des deux derniers millénaires) coordinated by A. Véron; a CNRS PEVS project (La forêt et le troupeau dans les Alpes du Sud du Tardiglaciaire à l'époque actuelle, à l'interface des dynamiques naturelles et des dynamiques sociales) coordinated by J. -L. de Beaulieu and Ph. Leveau; an ACI project (Savoir brûler) coordinated by A. Durand; a GDR Juralp project coordinated by F. Mocci (CCJ, Aix Marseille Université), M. Desmet (Edytem, Université de Savoie) and M. Magny (Université de Besançon). The Argentière municipality, the Regional Archaeological Service of PACA (administrative region Provence-Alpes-Côte d'Azur) and the French Ministry of Cultural affairs funded the archaeological excavation of the Argentière and Faravel mining districts directed by $B$. Ancel and V. Py. We thank for their contribution several CNRS and Aix Marseille Université laboratories among which the LA3M, the CCJ, the CEREGE and IMBE. We acknowledge the efficient cooperation of the Cultural Service of L'Argentière-La Bessée. C. Oberlin, in charge of the radiocarbon datation center of Université de Lyon 1, was of a great help for radiocarbon analyses. We acknowledge the support of the OSU-Institut Pytheas at Aix Marseille University. We are grateful to S. Chambers, E. Gil, N. de Munnik and I. Cowburn for English editing of the manuscript.

\section{References}

Abrahim, G.M.S., Parker, P.J., 2008. Assessment of heavy metal enrichment factors and the degree of contamination in marine sediment from Tamaki Estuary, Auckland, New Zealand. Environmental Monitoring and Assessment 136, 227238.

Ali, A.A., Carcaillet, C., Guendon, J.-L., Quinif, Y., Roiron, P., Terral, J.-F., 2003. The Early Holocene treeline in the southern French Alps: new evidence from travertine formations. Global Ecology and Biogeography 12, 411-419.

Ali, A.A., Roiron, P., Guendon, J.-L., Poirier, Ph, Terral, J.-F., 2005. Holocene vegetation responses to fire events in the inner French Alps (Queyras Massif): data from charcoal and geomorphological analysis of travertine sequences. The Holocene 15 (1), 149-155.

Allée, Ph, Paradis, S., Boumédiène, F., Rouaud, R., 2010. L’exploitation médiévale du plomb argentifère sur le mont Lozère : archéologie spatiale d'un territoire proto-industriel montagnard. In: Mines et métallurgies anciennes du plomb dans leurs environnements, proceedings of the International Conference of Florac. ArcheoSciences, Revue d'archéométrie, vol. 34, pp. 177-186.

Alleman, L., Hamelin, B., Veron, A.J., Miquel, J.C., Heussner, S., 2000. Lead sources, transfer in the coastal Mediterranean: evidence from stable lead isotopes in marine particles. Deep-sea Research Part II 47, 2257-2279.
Anagnost, S.E., Meyer, R.W., Zeeuw, C. de, 1994. Confirmation and significance of Bartholin's method for the identification of the wood of Picea and Larix. IAWA Journal 15, 171-181.

Ancel, B., 2006. Exploitations et indices de mines dans les Hautes-Alpes avant la Révolution. Cahiers du Château Saint-Jean n¹, Fournel. L'Argentière-La Bessée, pp. 89-101.

Ancel, B., 2008. Les vestiges en bois de la mine du Fournel à L'Argentière-La Bessée (Hautes-Alpes). In: Bailly-Maître, M.Ch, Jourdain-Annequin, C., ClermontJoly, M. (Eds.), Archéologie et paysage des mines anciennes : de la fouille au Musée. Picard, pp. 75-87.

Ancel, B., 2010. Les anciennes mines métalliques des Alpes du Sud : bilan diachronique. In: Tzortzis, S., Delestre, X. (Eds.), Archéologie de la montagne européenne, proceedings of the International workshop of Gap. Bibliothèque d'Archéologie Méditerranéenne et Africaine 4. Errance, Paris, pp. 293-300.

Ancel, B., 2012. Une mine métallique au XIX ${ }^{\mathrm{e}}$ siècle au cœur des Alpes : faits, procédures et arbitrages autour des conflits d'usages industriels et communautaires. Provence Historique LXII, fasc 250, 479-495.

Ancel, B., Py, V., Marconnet, Ch, Leleu, V., 2010. Une mine de plomb argentifère dans un environnement montagnard : la mine médiévale du Fournel à l'ArgentièreLa Bessée (Hautes-Alpes). In: Mines et métallurgies anciennes du plomb dans leurs environnements, proceedings of the International Conference of Florac. ArcheoSciences, Revue d'archéométrie, vol. 34, pp. 203-220.

Angelidis, M.O., Radakovitch, O., Veron, A., Aloupi, M., Heussner, S., Price, B., 2011. Pollutant metal and sapropel imprints in deep Mediterranean sediments. Marine Pollution Bulletin 62, 1041-1052.

Argant, J., Argant, A., 2000. Mise en évidence de l'occupation ancienne d'un site d'altitude: analyse pollinique du lac du Lauzon (Drôme). In: Géologie alpine, hors-série, vol. 31, pp. 61-71.

Arnaud, F., Serralongue, J., Winiarski, Th, Desmet, M., Paterne, M., 2005. Pollution au plomb dans la Savoie antique (II-IIIe s. ap. J.-C.) en relation avec une installation métallurgique de la cité de Vienne. Comptes Rendus Geoscience 338, 244-252.

Bailly-Maître, M.-Ch, 2002. L'argent, du minerai au pouvoir. Picard, Paris. 224 pp..

Barge, H., Talon, B., 2012. Attaque au feu au Bronze ancien sur le gîte de cuivre de Saint-Véran (Hautes-Alpes). Bulletin de la Société préhistorique française 109 $\left(n^{\circ} 1\right), 145-154$

Barge, H., 2006. Les minéralisations cuprifères et leurs exploitations dans le Sud-Est de la France. In: Barge, H. (Ed.), 4000 ans d'histoire des mines. L'exemple de la région Provence-Alpes-Côte d'Azur, Mélanges Jean-Paul Jacob, Theix. Actilia Multimédia, pp. 11-25.

Baron, S., Lavoie, M., Ploquin, A., Carigan, J., Pulido, M., Beaulieu, J.-L. de, 2005 Record of metal workshops in peat deposits: history and environmental impact on the Mont-Lozère Massif (France). Environmental Science and Technology 39, $5131-5140$.

Beaulieu, J.-L. de, 1977. Contribution pollenanalytique à l'histoire tardiglaciaire et holocène de la végétation des Alpes méridionales françaises (Ph.D. thesis) University of Aix-Marseilles III, 358 p., 29 fig., 39 diag. h.t.

Beaulieu, J.-L. de, Richard, H., Ruffaldi, P., Clerc, J., 1994. History of vegetation, climate and human action in the French Alps and the Jura over the last 15000 years. Dissertationes Botanicae 234, 253-275.

Beaulieu, J.-L. de, Leveau, P., Miramont, C., Palet, J.M., Walsh, K., Court-Picon, M. Ricou, F., Segard, M., Sivan, O., Andrieu-Ponel, V., Badura, M., Bertucchi, G., Boutterin, C., Durand, A., Édouard, J.-L., Lavoie, M., Morin, A., Mocci, F., Ponel, P., Pothin, A., Py, V., Talon, B., Tzortzis, S., Bonet, R., Columeau, P., Cortot, H., Garcia, D., 2003. Changements environnementaux postglaciaires et action de l'homme dans le bassin du Buëch et en Champsaur (Hautes-Alpes, France) Premier bilan d'une étude pluridisciplinaire. In: Muxart, T., Vivien, F.-D., Villalba, B., Burnouf, J. (Eds.), Des Milieux et des Hommes: Fragments d'Histoires Croisées, Collection Environnement. Elsevier, Paris, pp. 93-101.

Bielenin, K., 1974. Starożytne górnictwo i hutnictwo żelaza w Górach Świętokrzyskich. Pańswowe Wydawn, Naukowe, Warszawa, 278 p.

Billecard, L., 1890. Notice sur le dixième arrondissement forestier Hautes-Alpes. Bulletin de la société d'étude des Hautes-Alpes, Gap, 60-83.

Bintz, P., Argant, J., Chaix, L., Pelletier, D., Thiébault, S., 1999. L’Aulp-du-Seuil, un site d'altitude du Mésolithique et du Néolithique ancien (St-Bernard-du-Touvet, Isère) : études préliminaires. In: Thévenin, A., Bintz, P. (Eds.), L’Europe des derniers chasseurs. Peuplement et paléoenvironnement de l'Épipaléolithique et du Mésolithique, proceedings of the 5th International Conference UISPP, Commission XII. C.T.H.S., Grenoble, Paris, pp. 611-616.

Bollhöfer, A., Rosman, K.J.R., 2001. Isotopic source signatures for atmospheric lead: the Northern Hemisphere. Geochimica et Cosmochimica Acta 65 (11), 17271740 .

Bond, J., 2007. Medieval charcoal-burning in England. In: Klápste, J., Sommer, P. (Eds.), Arts and Crafts in Medieval Rural Environment, vol. 6. Ruralia, Turnhout Brepols Publishers, pp. 277-294.

Bonhôte, J., Davasse, B., Dubois, C., Izard, V., Métailié, J.-P., 2002. Charcoal kilns and environmental history in the eastern Pyrenees (France). A methodologica approach. In: Thiébault, S. (Ed.), Charcoal Analysis. Methodological Approaches, Palaeoecological Results and Wood Uses, Proceedings of the Second International Meeting of Anthracology, Paris, September, 2000, BAR International Series, vol. 1063, pp. 219-228.

Bonhôte, J., Vernet, J.-L., 1988. La mémoire des charbonnières. Essai de reconstitution des milieux forestiers dans une vallée marquée par la métallurgie (Aston, Haute-Ariège). Revue Forestière Française 40 (n³), 197-212.

Bourgarit, D., Rostan, P., Burger, E., Carozza, L., Mille, B., Artioli, G., 2008. The beginning of copper mass production in the southern part of western Alps : the 
Saint-Véran mining area considered (Hautes-Alpes, France). Historical Metallurgy 42 (1), 21-31.

Braunstein, Ph, 1986. Les mines anciennes, entre Lyonnais et Briançonnais : bilan et perspectives de recherches. In: Braemer, F. (Ed.), Les ressources minérales et l'histoire de leur exploitation, proceedings of the 108th Congrès national des Sociétés savantes. C.T.H.S., Grenoble, Paris, pp. 151-163.

Breitenlechner, E., Hilber, M., Lutz, J., Kathrein, Y., Unterkircher, A., Oeggl, K., 2010. The impact of mining activities on the environment reflected by pollen, charcoal and geochemical analyses. Journal of Archaeological Science 37, 14581467.

Brill, R.H., Wampler, J.M., 1967. Isotope studies of ancient lead. American Journal of Archaeology 71, 63-77.

Bronk Ramsey, C., 2009. Bayesian analysis of radiocarbon dates. Radiocarbon 51 (1), $337-360$.

Brugiapaglia, E., Beaulieu, J.-L. de, Guiot, J., Reille, M., 1998. Transect de pluie pollinique et étagement de la végétation dans le massif du Taillefer (Isère, France). Géographie physique et Quaternaire 52 (2), 209-218.

Buffault, P., 1910. Les forêts et pâturages du mandement de Guillestre. Extrait du bulletin de géographie historique et descriptive, $\mathrm{n}^{\circ} 1-2$. Paris, $31 \mathrm{pp}$.

Burri, S., Durand, A., Py, V., Vaschalde, Ch, 2013. Les outils pour acquérir et transformer la matière ligneuse dans les chaînes opératoires techniques des artisanats forestiers en Provence et Haut-Dauphiné au Moyen Âge. In: Anderson, P.C., Cheval, C., Durand, A. (Eds.), An Interdisciplinary Focus on Plant-Working Tools, Proceedings of the XXXIIIth Rencontres Internationales d'Archéologie et d'Histoire d'Antibes. Éditions APDCA, Antibes, pp. 397-414.

Carozza, L., Rostan, P., Bourgarit, D., Mille, B., Coquinot, Y., Burens, A., Artigas, N.E. 2010. Un site métallurgique du Bronze ancien dans le vallon du Longet à Molines-en-Queyras (Hautes-Alpes) : caractérisation du context archéologique et des déchets lies aux activités de métallurgie extractive. In: Tzortzis, S., Delestre, X. (Eds.), Archéologie de la montagne européenne, proceedings of the International workshop of Gap, Bibliothèque d'Archéologie Méditerranéenne et Africaine 4. Errance, Paris, pp. 261-281.

Cattin, F., Guénette-Beck, B., Curdy, Ph, Meisser, N., Ansermet, S., Hofmann, B. Kündig, R., Hubert, V., Wörle, M., Hametner, K., Günther, D., Wichser, A Ulrich, A., Villa, I.M., Besse, M., 2011. Provenance of Early Bronze Age metal artefacts in Western Switzerland using elemental and lead isotopic compositions and their possible relation with copper minerals of the nearby Valais. Journal of Archaeological Science 38, 1221-1233.

Chauvin, Ch, Vallauri, D., 2002. Indicateurs de restauration écologique de marnes dégradées dans les Alpes du Sud, 120 ans après reboisement. Revue Écologique (Terre Vie), 241-250. Supplément 9.

Chow, T.J., Bruland, K.W., Bertine, K.K., Soutar, A., Koide, M., Goldberg, E.D., 1973. Lead pollution: records in Southern California coastal sediments. Science 181 $551-552$.

Corona, C., Edouard, J.-L., Guiot, J., Guibal, F., Thomas, A., Saulnier, M., 2010 Reconstruction des températures estivales dans les Alpes françaises au moyen de données dendrochronologiques (749-2007 AD). In: Panorama de la dendrochronologie en France, Conference proceedings of Digne-les-Bains, vol. 11 Cahier de l'EDYTEM, Chambéry, pp. 167-174.

Corona, C., Edouard, J.-L., Guibal, F., Lambert, G.N., Py, V., Guiot, J., Thomas, A., 2011 Last-millennium summer-temperature variations in Brianconnais (French Alps) based on a composite tree-ring larch chronology. In: Proceedings of the Conference Tree rings Art, Archaeology, Royal Institute for Cultural Heritage, Collection Scientia Artis, vol. 7, pp. 49-65. Brussels.

Court-Picon, M., 2003. Approches palynologique et dendrochronologique de la mise en place du paysage dans le Champsaur (Hautes-Alpes, France) à l'interface des dynamiques naturelles et des dynamiques sociales. Thématique, méthodologie et premiers résultats. Archéologie du Midi Médiéval 21, 211-224.

Court-Picon, M., Walsh, K., Mocci, F., Segard, M., Palet-Martinez, J., 2007. Occupation de la montagne et transformation des milieux dans les Alpes méridionales au cours de l'âge du Bronze : approche croisée des données palyologiques et archéologiques en Champsaur et Argentiérois (Hautes-Alpes, France). In: Mordant, C., et al. (Eds.), Environnements et cultures à l'âge du Bronze en Europe occidentaleCTHS, Paris, pp. 89-106.

Cushing, E.J., 1967. Late-Wisconsin pollen stratigraphy and the glacial sequence in Minnesota. In: Cushing, E.J., Wright, H.E. (Eds.), Quaternary Palaeoecology. Yale University Press, New Haven and London, p. 59.

Davasse, B., 2000. Forêts, charbonniers et paysans dans les Pyrénées de l'Est, du Moyen Age à nos jours. Une approche géographique de l'histoire de l'environnement. GEODE, Toulouse, $287 \mathrm{pp}$

Davasse, B., Galop, D., 1989. Le charbon de bois et le pollen : éléments pour une approche de l'évolution historique du paysage forestier dans les Pyrénées ariégeoises. Acta Biologica Montana 9, 333-340.

Deboudt, K., Flament, P., Weis, D., Mennessier, J.P., Maquinghen, P., 1999. Assessment of pollution aerosols sources above the Straits of Dover using lead isotope geochemistry. Science of the Total Environment 236, 57-74.

Delwaide, A., Filion, L., 2010. Echantillonnage et datation dendrochronologique. In: Payette, S., Filion, L. (Eds.), La Dendroécologie, principes, méthodes et applications. Presse de l’Université Laval, Québec, pp. 167-197.

Doe, R.B., 1970. Lead Isotopes. Springer Verlag, Berlin.

Duce, R.A., Hoffman, G.L., Ray, B.J., et al., 1976. Trace metals in the marine atmosphere: sources and fluxes, 1976. In: Windom, H.L., Duce, R.A. (Eds.), Marine Pollutant Transfer. Heath and Company, Lexington Mass, pp. 77-119.
Durand, A., 2004. Du paysage à la pratique des gestes à l'environnement : essai d'approches croisées sur les systèmes agraires en France méridionale et en Catalogne (IXe-XVe siècles). HDR, University of Aix-Marseilles I. , 2 vol. 533 p.

Edouard, J.-L., 2010a. Longue chronologie de cernes du mélèze et occupation humaine depuis plus de mille ans dans la vallée de la Clarée (Briançonnais, Alpes françaises). In: Tzortzis, S., Delestre, X. (Eds.), Archéologie de la montagne européenne, proceedings of the International workshop of Gap, Bibliothèque d’Archéologie Méditerranéenne et Africaine 4. Errance, Paris, pp. 325-333.

Edouard, J.-L., 2010b. Datation dendrochronologique du bâti traditionnel et occupation humaine dans les Alpes françaises du Sud au cours du dernier millénaire. In: Proceedings of the Conference Panorama de la dendrochronologie en France, Digne-les-Bains, vol. 11. Cahier de l'EDYTEM, Chambéry, pp. 169-176.

Edouard, J.-L., Corona, C., Thomas, A., Touflan, P., 2010. Vieux arbres vivants et arbres morts (mélèzes, Larix decidua Mill. ; pins cembro, Pinus cembra L.) témoins des forêts du passé dans les Alpes du Sud : approche dendrochronologique d'un patrimoine. In: Vallauri, D., André, J., Génot, J.-C., De Palma, J.-P., EynardMachet, R. (Eds.), Biodiversité, Naturalité et Humanité. Pour inspirer la gestion des forêts. Editions Lavoisier - TEC\&DOC, pp. 141-145.

Edouard, J.-L., Thomas, A., 2008. Cernes d'arbres et chronologie holocène dans les Alpes françaises. In: Desmet, M., Magny, M., Mocci, F. (Eds.), Dynamique holocène de l'environnement dans le Jura et les Alpes : du climat à l'Homme, proceedings of the Workshop JurAlp, Aix en Provence, Collection Edytem, Cahiers de Géographie, vol. 6, pp. 179-190.

Erdtman, G., 1954. An Introduction to Pollen Analysis, second ed. Chronica Botanica, Waltham (Mass.), USA. 239 pp.

Falque-Vert, H., 1997. Les hommes et la montagne en Dauphiné au XIIIe siècle. PUG, Grenoble, 517 pp.

Falque-Vert, H., 2004. Les paysans et la terre en Dauphiné vers l'an mil. PUG, Grenoble, 323 pp.

Fauquette, S., 1995. Étude paléoécologique (pollen et macrorestes) d'un site du Brianconnais : le lac de Cristol (Hautes-Alpes, France). Palynosciences 3, 51-68.

Ferrand, J.L., Hamelin, B., Monaco, A., 1999. Isotopic tracing of sedimentary fluxes in the Gulf of Lions. Continental Shelf Research 19, 23-47.

Flament, P., Bertho, M.L. Deboudt, K. Véron, A. Puskaric, E, 2002. European isotopic signatures for lead in atmospheric aerosols: a source apportionment based upon 206Pb/207Pb ratios. Science of the Total Environment 296, 35-57.

Gale, N.H. Stos-Gale, Z.A., 1982. Lead and silver in the ancient Aegean. Scientific American 244 (6), 76-192.

Gale, N.H., Stos-Gale, Z.A., 2000. Lead isotope analyses applied to provenance studies. In: Ciliberto, E., Spoto, G. (Eds.), Modern Analytical Methods in Art and Archaeology, Chemical Analyses Series, vol. 155(17). John Wiley and Sons, Inc., New-York, pp. 503-584.

Gale, R., 2003. Wood-based industrial fuels and their environmental impact in lowland Britain. In: Murphy, P., Wiltshire, P.E.J. (Eds.), The Environmental Archaeology of Industry. Symposia of the Association for Environmental Archaeology, vol. 20, pp. 30-47.

Galop, D., Jalut, G., 1994. Differential human impact and vegetation history in two adjacent Pyrenean valleys in the Ariège basin, southern France, from 3000 BP to the present. Vegetation History and Archaeobotany 3, 225-244.

Galop, D., Monna, F., Beyrie, A., Carozza, L., Parent, G., 2006. Activités métallurgiques et environnement en vallée de Baïgorry (Pyrénées-Atlantiques) : une approche interdisciplinaire. In: Chauchat, C. (Ed.), Préhistoire du Bassin de l'Adour, Izpegi, pp. 277-303.

Garçon, M., Chauvel, C., Chapron, E., Faïn, X., Lin, M., Campillo, S., Bureau, S., Desmet, M., Bailly-Maître, M.-Ch, Charlet, L., 2012. Silver and lead in highaltitude lake sediments: proxies for climate changes and human activities. Applied Geochemistry 27, 760-773.

Gassiot, E., Pèlachs, A., Bal, M.-C., Garcia, V., Julià, R., Pérez, R., Rodríguez, D. Astrou, A.-C., 2010. Dynamiques des activités anthropiques sur un milieu montagnard dans les Pyrénées occidentales catalanes durant la Préhistoire : une approche multidisciplinaire. In: Tzortzis, S., Delestre, X. (Eds.), Archéologie de la montagne européenne, proceedings of the International workshop of Gap, Bibliothèque d'Archéologie Méditerranéenne et Africaine 4. Errance, Paris, pp. 33-43.

Geary, P.J., 1985. Aristocracy in Provence. The Rhône basin at the dawn of the Carolingian age. Monographien zur geschichte des mittelalters, Band 31. Anton Hiersemann, Stuttgart, $180 \mathrm{pp}$

Germanique, J.C., 1994. Major, trace and rare-earth elements in fourteen reference samples. Determination by X-Ray fluorescence spectrometry and inductively coupled plasma optical emission spectrometry. Geostandards Newsletter 18 (1), 91-100.

Greguss, P., 1955. Identification of living Gymnosperms on the Basis of Xylotomy. Akadémiai Kiadò, Budapest, 263 p., 350 pi. h. t. et 8 suppl.

Greguss, P., 1959. Holzanatomie der Europaïschen Laubhölzer und Sträucher. Akadémiai Kiadò, Budapest, 330 pp.

Guillaume, P., 1887. Les forêts des Hautes-Alpes en 1727-1728 et la question des déboisements d'après les documents officiels inédits. Bulletin de la société d'étude des Hautes-Alpes, 6ème année, Gap, 81-113.

Heiss, A.G., Oeggl, K., 2008. Analysis of the fuel wood used in Late Bronze Age and Early Iron Age copper mining sites of the Schwaz and Brixlegg area (Tyrol, Austria). Vegetation History and Archaeobotany 17, 211-221.

Hillebrecht, M.L., 1989. Untersuchungen an Holzkohlen aus frühen Schmelzplätzen. Der Anschnitt, Beiheft 7, 203-212. 
Hopper, J.F., Ross, H.B., Sturges, W.T., Barrie, L.A., 1991. Regional source discrimination of atmospheric aerosols in Europe using the isotopic composition of lead. Tellus 43B, 45-60.

Jouffroy-Bapicot, I., Pulido, M., Baron, S., Galop, D., Monna, F., Lavoie, M., Ploquin, A., Petit, Ch, Beaulieu, J.-L. de, Richard, H., 2007. Environmental impact of early palaeometallurgy: pollen and geochemical analyses. Vegetation History and Archaeobotany 16, 251-258.

Kharbouch, M., 2000. Variations altitudinales de quelques taxons végétaux dans les Alpes du Sud durant le Tardiglaciaire et l'Holocène. Quaternaire 11 (3-4), 231-242.

Lambert, G.-N., 1998. La Dendrochronologie, mémoire de l'arbre. In: Ferdière, A. (Ed.), La datation en laboratoire. Coll. « Archéologiques ». Errance, pp. 13-69.

Lambert, G.-N., 2006. Dendrochronologie, histoire et archéologie, modélisation du temps ; le logiciel Dendron II et le projet Historic Oaks, vol. 2. HDR, University of Franche-Comté, Besançon, 151 et 205 p.

Lambert, G.-N., 2011. Dendrochronology, Archaeology and science. In: Conference "Tree rings Art, Arcaheology", Brussels, 10-12th February 2010. Proceedings, published by the Royal Institute for Cultural Heritage, Collection Scientia Artis, vol. 7, pp. 19-30.

Lambert, G.-N., Bernard, V., Dupouey, J.-L., Fraiture, P., Gassmann, P., Girardclos, O., Lebourgeois, F., Ledigol, Y., Perrault, C., Tegel, W., 2010. Dendrochronologie et Dendroclimatologie du chêne en France. Questions posées par le transfert de données historiques vers la Dendroclimatologie. In: Panorama de la dendrochronologie en France, Conference proceedings of Digne-les-Bains, vol. 11. Cahier de l'EDYTEM, Chambéry, pp. 205-215.

Leveau, Ph, Segard, M., 2004a. Le pastoralisme en Gaule du sud entre plaine et montagne : de la Crau aux Alpes du Sud. PALLAS, vol. 64. Presses Universitaires du Mirail, pp. 99-113.

Leveau, Ph, Segard, M., 2004b. L'occupation de la haute montagne dans les Alpes du Sud à l'époque romaine. Premiers résultats d'une recherche dans les HautesAlpes (Buëch, Champsaur, Briançonnais). In: Daudry, D. (Ed.), Proceeding of the 10th International Conference of Cogne (Italy), Bulletin d'Études Préhistoriques et Archéologiques Alpines, XV, pp. 229-242.

Lucas, A., Harris, J.R., 1962. Ancient Egyptian Materials and Industries. Arnol E., London.

Ludemann, T., 1995. Zwei Kohlplätze im Mittleren Schwarzwald. - Mitt. bad. Landesver. Naturkunde und Naturschutz 16 (2), 319-334.

Ludemann, T., Nelle, O., 2002. Die Wälder am Schauinsland und ihre Nutzung durch Bergbau und Köhlerei. Forstliche Versuchs- und Forschungsanstalt, BadenWürttemberg, Abteilung Botanik und Standortskunde, Freiburg (Breisgau), Forstliche Versuchs- und Forschungsanstalt, Baden-Württember, 139 pp.

Maggiori, L., 2001. Les incidences techniques de l'utilisation des boisages et des équipements en bois sur l'architecture des réseaux miniers (de l'Antiquité jusqu'au XVIe siècle). Master 2, vol. 1. University of Provence, Aix-Marseilles I, $120 \mathrm{pp}$.

Marcantonio, F., Zimmerman, A., Xu, Y., Canuel, E., 2002. A Pb isotope record of midAtlantic US atmospheric Pb emissions in Chesapeake Bay sediments. Marine Chemistry 77, 123-132.

Marguerie, D. Hunot, J.-Y., 2007. Charcoal analysis and dendrology : data from archaeological sites in western France. Journal of Archaeological Science 34, 1417-1433.

Martinez Cortizas, A., Peiteado Varela, A., Bindler, R., Biester, H., Cheburkin, A., 2012. Reconstructing historical $\mathrm{Pb}$ and $\mathrm{Hg}$ pollution in NW Spain using multiple cores from the Chao de Lamoso bog (Xistral Mountains). Geochimica et Cosmochimica Acta 82, 68-78.

Mc Lennan, S.M., 1995. Sediments and soils: chemistry and abundances. In: Rock Physics and Phase Relations, a Handbook of Physical Constants, AGU Ref. Shelf 3, Ed. AGU.

Métailié, J.-P., Bonhôte, J., Fruhauf, C., 1988. A thousand years of forest history in the french Pyrenees mountains : the Ariege example. Human Influence on Forest Ecosystems Development in Europe. ESF FERN-CNR, Bologne, pp. 159-167.

Meyer, D., 1981. La végétation des vallées de Vallouise, du Fournel et de la Byaisse (Pelvoux oriental - Hautes-Alpes). Analyse phytosociologique et phytogéographique des étages collinéen, montagnard et subalpin (Ph.D. thesis). University of Provence, Aix-Marseilles I, 176 p.

Mighall, T.M., Timberlake, S., Clark, S.H.E., Caseldine, A.E., 2002a. A palaeoenvironmental investigation of sediments from the prehistoric mine of Copa Hill, Cwmystwyth, mid-Wales. Journal of Archaeological Science 29, 1161-1188.

Mighall, T.M., Abrahams, P.W., Grattan, J.P., Hayes, D., Timberlake, S., Forsyth, S., 2002b. Geochemical evidence for atmospheric pollution derived from prehistoric copper mining at Copa Hill, Cwmystwyth, mid-Wales, U.K. Science of the Total Environment 292, 69-80.

Monna, F., Galop, D., Carozza, L., Tual, M., Beyrie, A., Marembert, F., Chateau, C., Dominik, J., Grousset, F., 2004. Environmental impact of early Basque mining and smelting recorded in a high ash minerogenic peat deposit. Science of the Total Environment 327, 197-214.

Montanari, C., Prono, P., Scipioni, S., 2000. The study of charcoal-burning sites in the Apennine Mountains of Liguria (NW Italy) as a tool for forest history. In: Agnoletti, M., Anderson, S. (Eds.), Methods and Approaches in Forest History. CABI Publishing, CAB International, Wallingford, pp. 79-91.

Morin, D., Rosenthal, P., 2006. Mines et minerais de fer de Provence et des Alpes du Sud. In: Barge, H. (Ed.), 4000 ans d'histoire des mines. L'exemple de la région Provence-Alpes-Côte d'Azur. Mélanges Jean-Paul Jacob. Theix. Actilia Multimédia, pp. 113-133.
Nakagawa, T., Edouard, J.-L., Beaulieu, J.-L. de, 2000. A scanning electron microscopy (SEM) study of sediments from lake Cristol, southern French Alps, with special reference to the identification of Pinus cembra and other Alpine Pinus species based on SEM pollen morphology. Review of Palaeobotany and Palynology 108, $1-15$.

Ng, A., Patterson, C.C., 1982. Changes of lead and barium with time in California offshore basin sediments. Geochimica et Cosmochimica Acta 46, 2307-2321.

Nriagu, J.O., 1983. Lead and Lead Poisoning in Antiquity. Wiley, New-York, 434 pp.

Ollivier, P., Hamelin, B., Radakovitch, O., 2010. Seasonal variations of physical and chemical erosion: a three-year survey of the Rhone river (France). Geochimica et Cosmochimica Acta 74, 907-927.

Overbeck, F., 1958. Pollenanalyse quartärer Bildungen. In: Freund, H., et al. (Eds.), Handbuch der Mikroskopie in der Technik, pp. 325-410. Frankfurt/Main.

Palet-Martinez, J.M., Ricou, F., Segard, M., 2003. Prospections et sondages sur les sites d'altitude en Champsaur (Alpes du Sud). Archéologie du Midi Médiéval 21 $199-210$.

Pichler, T., Nicolussi, K., Goldenberg, G., 2009. Dendrochronological analysis and dating of wooden artefacts from the prehistoric copper mine Kelchalm/Kitzbühel (Austria). Dendrochronologia 27, 87-94.

Ponel, Ph, Beaulieu, J.-L. de, Tobolski, K., 1992. Holocene palaeoenvironments at the timberline in the taillefer massif, French Alps: a study of pollen, plant Macrofossils and Fossil insects. The Holocene 2 (2), 117-130.

Py, V., 2006. Mine charcoal deposits : methods and strategies. The medieval Fournel silver mines in the Hautes-Alpes (France). In: Dufraisse, A. (Ed.), Charcoal analysis : New analytical tools and methods for archaeology. Papers from the table-ronde held in Basel, Oxford, British Archaeological Reports Internationa Series S, vol. 1483. Archaeopress, pp. 35-46.

Py, V., 2009. Mine, bois et forêt dans les Alpes du Sud au Moyen Âge. Approches archéologique, bioarchéologique et historique. Ph.D. thesis. University of de Provence Aix-Marseilles I, 3 vol., 1-2, 1332 p., 3, 116 p.

Py, V., 2010. Techniques et usages du bois des mineurs à Faravellum aux XI ${ }^{\mathrm{e}}-\mathrm{XIII}^{\mathrm{e}} \mathrm{s}$ (Freissinières, Hautes-Alpes). In: Delhon, Cl, Théry-Parisot, I., Thiébault, S. (Eds.), Des hommes et des plantes. Exploitation du milieu et des ressources végétales de la Préhistoire à nos jours, proceedings of the XXXth Rencontres Internationales d'Archéologie et d'Histoire d'Antibes. Éditions APDCA, Antibes, pp. 293-321.

Py, V., Ancel, B., 2007. Exploitation des mines métalliques de la vallée de Freissinières (Hautes-Alpes, France) : contribution à l'étude de l'économie sud-alpine aux IX ${ }^{\mathrm{e}}$-XIII ${ }^{\mathrm{e}}$ siècles. Preistoria Alpina 42, 83-93.

Py, V., Ancel, B., Marconnet, Ch, 2012. De l'usage minier du feu: sources et expérimentations. Cahier d'Histoire des Techniques, vol. 8. Publications de l'Université de Provence, pp. 133-153.

Py, V., Durand, A., Ancel, B., 2013. Anthracological analysis of wood fuel used for firesetting in medieval metallic mines of the Faravel district (southern French Alps). Journal of Archaeological Science 40, 3878-3889.

Reille, M., 1992. Pollen et spores d'Europe et d'Afrique du Nord. CNRS, Marseille. XXIII-520 pp.

Reille, M., 1995. Pollen et spores d'Europe et d'Afrique du Nord. Supplément 1. CNRS, Marseille, 327 pp.

Reille, M., 1998. Pollen et spores d'Europe et d'Afrique du Nord. Supplément 2. CNRS, Marseille, $530 \mathrm{pp}$.

Reimer, P.J., Baillie, M.G.L., Bard, E., Bayliss, A., Beck, J.W., Blackwell, P.G., Bronk Ramsey, C., Buck, C.E., Burr, G.S., Edwards, R.L., Friedrich, M., Grootes, P.M., Guilderson, T.P., Hajdas, I., Heaton, T.J., Hogg, A.G., Hughen, K.A., Kaiser, K.F. Kromer, B., McCormac, F.G., Manning, S.W., Reimer, R.W., Richards, D.A. Southon, J.R., Talamo, S., Turney, C.S.M., van der Plicht, J., Weyhenmeyer, C.E. 2009. IntCal09 and Marine09 radiocarbon age calibration curves, $0-50,000$ years cal BP. Radiocarbon 51 (4), 1111-1150.

Renberg, I., Wik-Persson, M., Emteryd, O., 1994. Pre-industrial atmospheric lead contamination detected in Swedish lake sediments. Nature 368, $323-$ 326.

Richer, S., 2009. From Pollen to People : the Interaction Between People and Their Environment in the mid- to High- Altitudes of the Southern French Alps (Ph.D thesis), vol. 2. University of York, UK, University Paul Cezanne Aix-Marseilles, $350 \mathrm{pp}$.

Schweingruber, F.H., 1978. Mikroskopische holzanatomic : Anatomie microscopique du bois. Birsmensdorf, Institut Fédéral de Recherches Forestières (Suisse), Zürcher AG, Zug, 226 pp.

Schweingruber, F.H., 1988. Tree-rings - Basics and Applications of Dendrochronology. Kluwer, Dordrecht, 277 pp.

Schweingruber, F.H., 1990. Anatomie europäischer hölzer : Anatomie of European woods. Haupt, Stuttgart, 800 pp.

Segard, M., 2009. Les Alpes occidentales romaines. Développement urbain et exploitation des ressources des régions de montagne (Gaule Narbonnaise, Italie, provinces alpines). Bibliothèque d'Archéologie Méditerranéenne et Africaine. vol. 1. Errance, Aix-en-Provence, 285 pp.

Segard, M., Walsh, K., Court-Picon, M., 2003. L'occupation de la haute montagne dans les Alpes occidentales. Apport de l'archéologie et des analyses paléoenvironnementales. In: Boëtsch, G., Devriendt, W., Piguel, A. (Eds.), Permanences et changement dans les sociétés alpines : État des lieux et perspectives de recherches. Edisud, Aix-en-Provence, pp. 17-30.

Selvaraj, K., Ram Mohan, V., Szefer, P., 2004. Evaluation of metal contamination in coastal sediments of the Bay of Bengal, India: geochemical and statistical approaches. Marine Pollution Bulletin 49, 174-185. 
Serre, F., 1978. The dendroclimatological value of European larch (Larix Decidua Mill.) in the French Maritime Alps. Tree-ring Bulletin 38, 25-34.

Shirahata, H., Elias, R.W., Patterson, C.C., Koide, M., 1980. Chronological variations in concentrations and isotopic compositions of anthropogenic lead in sediments of a remote subalpine pond. Geochimica et Cosmochimica Acta 44, 149-162.

Shotyk, W., 2002. The chronology of anthropogenic, atmospheric Pb deposition recorded by peat cores in three minerogenic peat deposits from Switzerland. Science of the Total Environment 292, 19-31.

Shotyk, W. Weiss, D., Appleby, P.G., Cheburkin, A.K., Frei, R., Gloor, M., et al., 1998. History of atmospheric lead deposition since 12,370 14C yr BP recorded in a peatbog profile, Jura Mountains, Switzerland. Science 281, 1635-1640.

Stos-Gale, Z.A., Gale, N.H., 1982. Sources of Mycenaean silver and Lead. Journal of Fioeld Archaeology 9, 467-485.

Stos-Gale, Z.A., Gale, N.H., 2009. Metal provenancing using isotopes and the Oxford archaeological lead isotope database (OXALID). Archeological and Anthropological Science 1(3) (3), 195-213.

Stos-Gale, Z.A., Gale, N.H., Annetts, N., 1996. Lead isotope data from the Isotrace Laboratory, Oxford: Archaeometry data base 3, ores from the Aegean, part 1 Archaeometry 38, 381-390.

Talon, B., 1997. Étude anatomique et comparative de charbons de bois de Larix decidua Mill. et de Picea abies (L.) Karst. Compes rendues Acadmie des sciences 320, 581-588.

Talon, B., 2010. Reconstruction of Holocene high-altitude vegetation cover in the French southern Alps: evidence from soil charcoal. The Holocene 20 (1), 35-44.

Téreygeol, F., Dubois, Cl, 2003. Mines et métallurgie carolingiennes à Melle (DeuxSèvres, France) : l'apport des charbons de bois archéologiques. Archéologie médiévale 33, 91-102.

Tessier, L., 1986. Chronologie de mélèzes des Alpes et Petit Age Glaciaire. Dendrochronologia 4, 97-113.

Thevenon, F. Guédron, S., Chiaradia, M., Loizeau, J.L., Poté, J., 2011. (Pre-) historic changes in natural and anthropogenic heavy metals deposition inferred from two contrasting Swiss Alpine lakes. Quaternary Science Reviews 30, 224-233.

Touflan, P., Talon, B., Walsh, K., 2010. Soil charcoal analysis: a reliable tool for spatially precise studies of past forest dynamic: a case study in the French southern Alps. The Holocene 20 (1), 45-52.

Vernet, J.-L., Ogereau, P., Figueiral, I., Machado Yanes, C., Uzquiano, P., 2001. Guide d'identification des charbons de bois préhistoriques et récents, Sud-Ouest de l'Europe : France, Péninsule ibérique et Îles Canaries. CNRS, Paris, 395 pp.

Véron, A., Flament, P., Bertho, M.L., Alleman, L., Flegal, A.R., Hamelin, B., 1999. Isotopic evidence of pollutant Pb sources in Northwestern France. Atmosphere and Environment 33, 3377-3388.

Walsh, K., Richer, S., Beaulieu, J.-L. de, 2006. Attitudes to altitude : changing meanings and perceptions within a « marginal » Alpine landscape - the integration of palaeological and archaeological data in a high altitude landscape in the French Alps. World Archaeology 38, 436-454.

Walsh, K., Mocci, F., Tzortzis, S., Bressy, C., Talon, B., Richer, S., Court-Picon, M. Dumas, V., Palet-Martinez, J., 2010. Les Écrins, un territoire d'altitude dans le contexte des Alpes occidentales de la Préhistoire récente à l'âge du Bronze (HautesAlpes, France). In: Tzortzis, S., Delestre, X. (Eds.), Archéologie de la montagne européenne. Proceedings of the International workshop of Gap. Bibliothèque d'Archéologie Méditerranéenne et Africaine 4. Errance, Paris, pp. 211-225.

Walsh, K., Court-Picon, M., Beaulieu, J.-L. de, Guiter, F., Mocci, F., Richer, S., Sinet, R. Talon, B., Tzortzis, S., 21 September 2014. A Historical ecology of the Ecrins (Southern French Alps): archaeology and palaeoecology of the Mesolithic to the Medieval period. Quaternary International 353, 52-73.

Wedepohl, K.H., 1995. The composition of the continental crust. Geochimica et Cosmochimica Acta 59, 1217-1232.

Woitke, P., Wellmitz, J., Helm, D., Kube, P., Lepom, P., Litheraty, P., 2003. Analysis and assessment of heavy metal pollution in suspended solids and sediments of the river Danube. Chemosphere 51, 633-642. 